Article

\title{
Eco-Efficiency Assessment and Food Security Potential of Home Gardening: A Case Study in Padua, Italy
}

\author{
Esther Sanyé-Mengual ${ }^{1}$ * (D), Daniela Gasperi ${ }^{1}$, Nicola Michelon ${ }^{1}$, Francesco Orsini ${ }^{1}$ (D), \\ Giorgio Ponchia ${ }^{2}$ and Giorgio Gianquinto ${ }^{1}$ (1) \\ 1 Research Centre in Urban Environment for Agriculture and Biodiversity (ResCUE-AB), Department of \\ Agricultural Sciences (DipSA), University of Bologna, 40127 Bologna, Italy; \\ daniela.gasperi87@gmail.com (D.G.); nicola.michelon@unibo.it (N.M.); f.orsini@unibo.it (F.O.); \\ giorgio.gianquinto@unibo.it (G.G.) \\ 2 Dipartimento di Agronomia Animali Alimenti Risorse Naturali e Ambiente (DAFNAE), Università degli \\ Studi di Padova, 35020 Padova, Italy; giorgio.ponchia@unipd.it \\ * Correspondence: esther.sanye@unibo.it; Tel.: +39-051-20-966-41
}

Received: 31 March 2018; Accepted: 13 June 2018; Published: 21 June 2018

check for updates

\begin{abstract}
In the expanding urban agriculture phenomenon in Europe, home gardens are a traditional form that have kept agriculture within cities, even becoming crucial in certain historical periods (e.g., war periods). However, horticultural practices in home gardens can also have negative consequences. The goal of this paper is to assess the eco-efficiency of home gardens as a type of urban agriculture. To do so, a case study in Padua (Italy) was evaluated following life cycle assessment and life cycle costing methods. A home garden of $30.6 \mathrm{~m}^{2}$ and 21 crop cycles were evaluated. The functional unit of the assessment was $1 \mathrm{~kg}$ of harvested fresh vegetable at the consumption point, and the ReCiPe method was employed for impact assessment. Environmental assessment indicated that organic fertilization, use of tap water, mineral fertilization and pesticides were the most contributing elements of the entire life cycle. Furthermore, the relevance of garden design and crop selection was a determinant in the eco-efficiency results. The assessed home garden could satisfy the food requirements of between 1 and 2 members of the household. Crop management and design recommendations are provided to improve eco-efficiency and food security potential of home gardens.
\end{abstract}

Keywords: urban agriculture; environmental impact assessment; local food production; life cycle assessment; urban food systems; sustainability; industrial ecology; food sovereignty; economic assessment; life cycle costing

\section{Introduction}

Vegetable production in cities has become a relevant topic as a result of urbanization and concentration of world population in urban areas [1], which place stress on both urban food security and environmental quality [2]. This demographic pressure has not only resulted in an urban sprawl that has negatively affected the environment-by impacting arable land, water, energy, biological resources [3], and waste generation [4] —but has also increased dependency on external sources of food [5]. Urban food demand has been satisfied by the development of conventional food systems that are based on industrialized and global supply-chains associated to environmental stresses [6]. Achieving sustainable food systems requires a renovation that promotes "in loco" [7] and environmentally-just [6] food production and consumption, and cities have become key spaces to integrate green and edible vegetation [8] for this purpose. Although urban agriculture (UA) literature 
has proliferated, the quantification of the contribution of UA to sustainability is recent and still under discussion.

\subsection{A Renewed Urban Agriculture}

UA typologies (such as backyard gardens) have always been present in cities but the recent global economic crisis of 2008 brought back agriculture into cities in a wide and diverse manner. The increase of "food deserts" [9] and financial limitations of certain groups in the society has promoted the creation of urban gardens to tackle food insecurity [10,11], as already performed during war periods [12]. The emergence of UA, such as community gardens, was essential to cope with urban social injustices, which were accentuated during crisis times. It helped build communities and empower the society, as well as regenerate abandoned and degraded spaces [13-18], such as in shrinking cities $[19,20]$ and post-disaster resilience [21]. In particular, UA also had a key role in the food justice movement [22] that aimed at tackling the disconnection between food production and consumption, and food and culture. Reynolds and Cohen [23] described the food justice dynamics and the role of UA in New York City, where unequal access to food and resources was often rooted in race and class differences. Such developments resulted in the sprout of a multifunctional and versatile UA within the context of the boosting of a renewed local food sector as an alternative food system [24].

This renovated UA has not only gained the attention of architects and urban planners, but also new entrepreneurs and innovators. UA designs currently include and integrate elements from the 19th century Howard's 'garden city' concept [25] into high-technology and resource-efficient production techniques [26-28]. Marginal spaces in urban periphery have been replaced by vacant spaces as locations for UA in the urban fabric - such as rooftops, walls or buildings-by employing vertical and indoor farming systems [29,30]. Although the opportunities offered by urban food businesses are pushing for an entrepreneurial UA [31], urban farms might engage city-adjusted strategies in order to be more successful [32].

As a result of this process, multiple definitions of UA have proliferated, although the primary function of producing food-mainly crops and livestock-has remained as a framework notion [33]. Furthermore, the production of non-food products has been also been included as part of the provisionary functions of UA [34,35]. Sanyé-Mengual [36] evaluated available definitions and identified four main variable aspects: space, production, function, and market. Within COST Action Urban Agriculture Europe [37], scholars made an effort to propose a comprehensive definition of UA:

"farming operations taking place in and around the city that beyond food production provides environmental services (soil, water, and climate protection; resource efficiency; biodiversity), social services (social inclusion, education, health, leisure, cultural heritage), and supports local economies by a significant direct urban market orientation" [38].

\subsection{Home Gardens}

Among the diverse UA methods, home gardens have expanded via private spaces that have turned into productive land, contributing to individual, household, and community food security [39] (i.e., the condition in which "all community residents obtain a safe, culturally acceptable, nutritionally adequate diet through a sustainable food system that maximizes community self-reliance and social justice" (p. 37) [40]). In particular, home gardens in the Global North have been crucial in specific historical events (e.g., wars and economic depressions) [12] and are a permanent form of agriculture in cities, increasing the vegetable and fruit uptake of the urban population quantitatively and qualitatively [41]. In fact, the total urban area devoted to private UA can be larger than the public UA area, such as for Chicago (United Sates) [42] or Rome (Italy) [43]. Taylor and Lovell [44] defined a home garden as a "garden managed by a single household on owned, rented or borrowed land, either on the same property as the residence or on adjacent land such as vacant lot, tree lawn or right of way (p. 2)". 
Research on home gardens has focused on seven main aspects: food security and access, resistance and empowerment, community development, social and cultural reproduction, biodiversity and ecological properties, agrobiodiversity and resilience [45]. Kortright and Wakefield [39] developed a home garden type, based on the five main motivations for gardeners: cook's gardens, teaching gardens, environmental gardens, hobby gardens and aesthetics gardens. This study also highlighted the contribution of home gardens to food security and accessibility, health and nutrition, and well-being. Taylor and Lovell [44] evaluated home gardens in households with different cultural backgrounds in Chicago (United States), demonstrating the positive role of home gardens in food security (both at household and community levels), in culturally acceptable foods' accessibility and in urban agrobiodiversity.

On the contrary, horticultural practices in home gardens can also have negative consequences, such as dependence on external inputs (e.g., chemicals, water, energy) and the negative impacts of their use [39]. In this line, a study on home gardens in Australia assessed the variables affecting water consumption in gardens, underlining the role of lifestyle and garden management practices [46]. However, no study have quantified the environmental impacts of urban food production in home gardens-thereby considering all the external inputs and the resulting productivity, unlike other typologies of UA (e.g., rooftop agriculture, community gardening, aquaponics) [47-55].

\subsection{Goal and Objectives}

The goal of this paper was to assess the eco-efficiency and food security potential of home gardens as a type of urban agriculture. The specific objectives were to address the following research questions:

- What are the environmental burdens of home gardens?

- What is the economic balance of vegetables production in home gardens?

- How can garden design and management promote eco-efficiency?

- How does a home garden contribute to the food security of home gardeners?

To do so, a case study in Padua (Italy) has been assessed, employing life cycle assessment (LCA) and life cycle costing (LCC) methods.

\section{Materials and Methods}

\subsection{Case Study}

The case study was a home garden located in Padua, Italy (Figure 1a). The garden had a total surface of $30.6 \mathrm{~m}^{2}$ divided into different plots that accounted for a total productive area of $25 \mathrm{~m}^{2}$ : nine parcels of $2 \times 1 \mathrm{~m}$, and two of $3.5 \times 1 \mathrm{~m}$ (Figure $1 \mathrm{~b}$ ). In the home garden, 11 different vegetables were produced in 21 crop cycles (Figure 1c), including both leafy and fruit vegetables. Data was collected between 2012 and 2013, when cultivation was performed, including autumn-winter and spring-summer cycles varying from 51 to 216 days. 


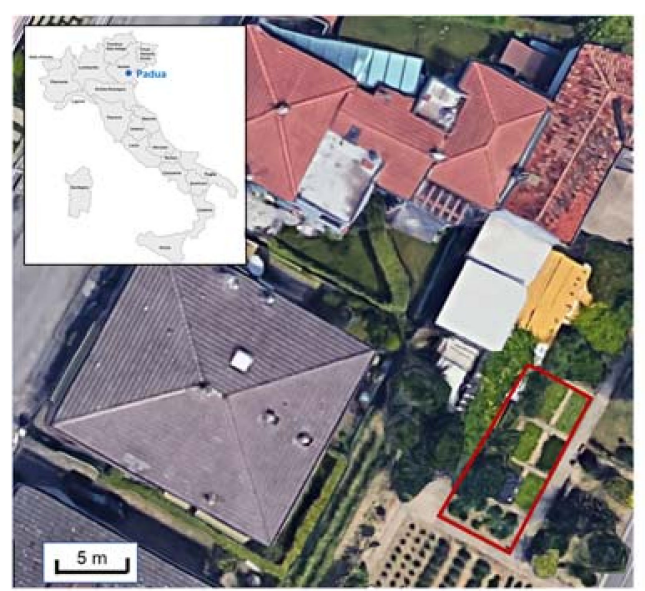

(a)

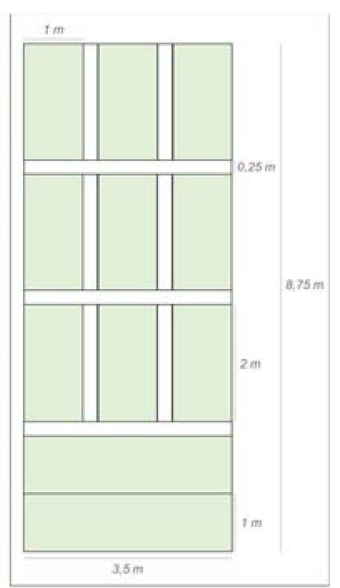

(b)

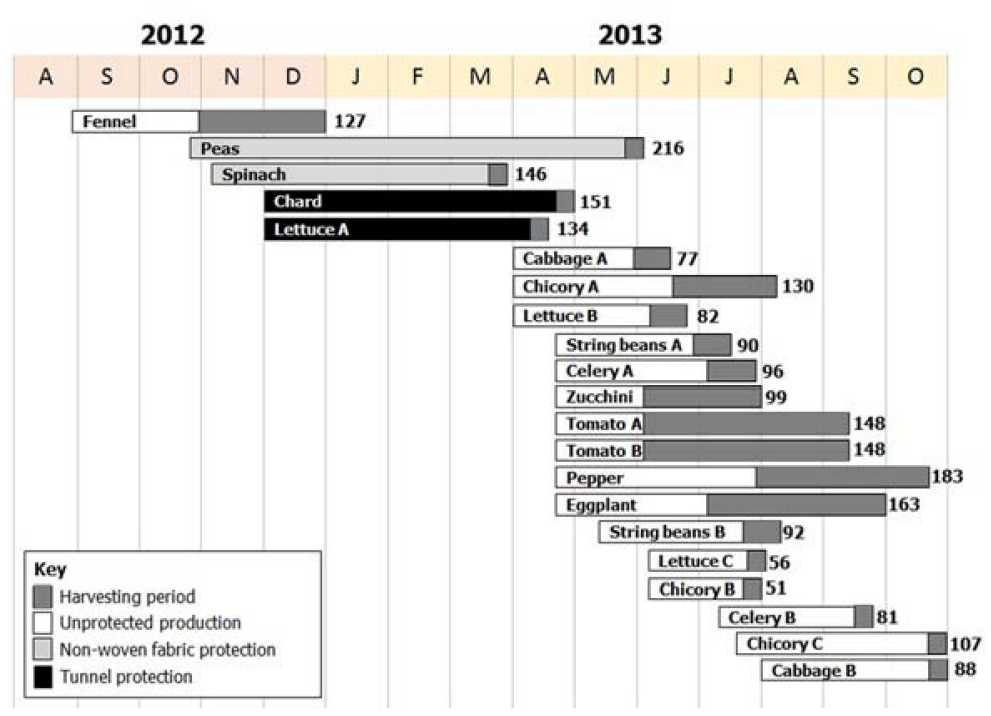

(c)

Figure 1. Case study specifications: (a) Location of Padua (Italy) and aerial image of the home garden (CGoogle Earth); (b) Design and dimensions of the garden and the plots; (c) Calendar of experimental crops, including crop cycle (days).

Regarding the agronomical characteristics of the garden (Table 1), soil cultivation was performed on the entire plot. The area devoted to each crop ranged from $0.5 \mathrm{~m}^{2}$ to $4 \mathrm{~m}^{2}$. Irrigation was done with tap water, using a dripline irrigation system $\left(10\right.$ drippers. $\left.\mathrm{m}^{-2}\right)$ and manually, thereby excluding any electronic device as auxiliary equipment (e.g., timer, pump). Irrigation rate depended on the crop cycle and the amount of cold days (Tc) $\left(5 \mathrm{~L} \cdot \mathrm{m}^{-2} \cdot\right.$ day $\left.^{-1}\right)$ and warm days $(\mathrm{Tw})\left(7 \mathrm{~L} \cdot \mathrm{m}^{-2} \cdot\right.$ day $\left.^{-1}\right)$. Pest control treatments were performed only once per crop a few days after transplanting using $25 \mathrm{~L}$ of copper oxychloride at a concentration rate of $3.5 \mathrm{~g} \cdot \mathrm{L}^{-1}$. No energy consumption was required during the crop production, as the operations were performed manually. The vegetables were harvested for the gardener's self-consumption. Some agronomic practices were done homogeneously in the garden, while others depended on the crop (Table 1):

- $\quad$ Soil preparation (SP): Soil was manually dug and aerated as preparation for the crops.

- Protected crops (PC): Autumn-winter cycles of peas, spinach, chard and lettuces were protected with non-woven fabric. While only seedlings were protected for peas, tunnels were installed for the rest of the crops. 
- Seeding (S) and Transplanting (TP): Commercial seeds or seedlings were used in the garden, depending on the crop and variety.

- Organic fertilization (OF): During soil preparation, plant nutrition was provided to all the crops homogeneously with initial fertilization of industrial compost (dosage of $1 \mathrm{~kg} \cdot \mathrm{m}^{-2}$ ).

- Mineral fertilization (MF): Fertilization was completed with a mineral fertilization with NPK (6-12-24) (dosage of $\left.75 \mathrm{~g} \cdot \mathrm{m}^{-2}\right)$ and ammonium nitrate $\left(\mathrm{NH}_{4} \mathrm{NO}_{3}\right)\left(\right.$ dosage of $\left.25 \mathrm{~g} \cdot \mathrm{m}^{-2}\right)$ for most of the crops.

- Crop rotation (CR): In two occasions, mineral fertilization was avoided as crops (i.e., lettuce, chicory) occurred after legumes (i.e., string beans) and nitrogen content was considered optimal.

Table 1. Specifications of the crops under assessment, including area $\left(\mathrm{m}^{2}\right)$, crop cycle (T, days) — differentiating between cold days (Tc) and warm days (Tw), yield $\left(\mathrm{kg} \mathrm{m}^{-2}\right)$ and agronomic practices (soil preparation, SP; protected crop, PC; seeds, S; transplant of seedlings, TP; organic fertilization, OF; mineral fertilization, MF; and crop rotation, $\mathrm{CR})$ ( $\mathrm{X}$ indicates when a practice occurs).

\begin{tabular}{|c|c|c|c|c|c|c|c|c|c|c|c|c|c|}
\hline \multirow{2}{*}{\multicolumn{2}{|c|}{ Crop }} & \multirow{3}{*}{$\begin{array}{c}\text { Area } \\
\left(\mathrm{m}^{2}\right) \\
4\end{array}$} & \multicolumn{3}{|c|}{ Cycle (Days) } & \multirow{2}{*}{$\begin{array}{l}\text { Yield } \\
\left(\mathrm{kg} \cdot \mathrm{m}^{-2}\right)\end{array}$} & \multirow{3}{*}{$\begin{array}{l}\text { SP } \\
x\end{array}$} & \multicolumn{4}{|c|}{ Agronomic Practices } & \multirow{3}{*}{$\frac{\text { MF }}{X}$} & \multirow{3}{*}{$\mathrm{CR}$} \\
\hline & & & $T$ & Tc & Tw & & & PC & $\mathrm{S}$ & TP & OF & & \\
\hline Fennel & $\begin{array}{l}\text { Foeniculum } \\
\text { vulgare }\end{array}$ & & 127 & 90 & 37 & 8.3 & & & & $\begin{array}{c}\mathrm{X} \\
(48)\end{array}$ & $x$ & & \\
\hline Peas & $\begin{array}{l}\text { Pisum } \\
\text { sativum }\end{array}$ & 4 & 216 & 182 & 34 & 2.4 & $x$ & $x$ & $\begin{array}{l}X(250 \\
\mathrm{g})\end{array}$ & & $x$ & $x$ & \\
\hline Spinach & $\begin{array}{l}\text { Spinacia } \\
\text { oleracea }\end{array}$ & 1 & 146 & 146 & 0 & 3 & $x$ & $x$ & $\begin{array}{c}X(20 \\
\mathrm{g})\end{array}$ & & $x$ & & \\
\hline Chard & $\begin{array}{c}\text { Beta } \\
\text { vulgaris }\end{array}$ & 0.7 & 151 & 151 & 0 & 10 & $x$ & $\mathrm{X}$ & & $\begin{array}{c}X \\
(12) \\
\end{array}$ & $\mathrm{x}$ & & \\
\hline $\begin{array}{c}\text { Lettuce } \\
\text { “Cappuccia” }\end{array}$ & $\begin{array}{l}\text { Lactuca } \\
\text { sativa }\end{array}$ & 1.3 & 134 & 134 & 0 & 3 & $x$ & $x$ & & $\begin{array}{c}\mathrm{X} \\
(12)\end{array}$ & $x$ & & \\
\hline $\begin{array}{c}\text { Cabbage } \\
\text { "Cappuccio" }\end{array}$ & $\begin{array}{l}\text { Brassica } \\
\text { oleracea }\end{array}$ & 1 & 77 & 32 & 45 & 4.7 & $x$ & & & $X(6)$ & $x$ & $x$ & \\
\hline $\begin{array}{l}\text { Chicory } \\
\text { "Grumulo" }\end{array}$ & $\begin{array}{l}\text { Cichorium } \\
\text { intybus }\end{array}$ & 1 & 130 & 32 & 98 & 7.7 & $x$ & & $\begin{array}{c}\mathrm{X} \\
(1.5 \\
\mathrm{g})\end{array}$ & & $x$ & $x$ & \\
\hline $\begin{array}{l}\text { Lettuce } \\
\text { "Gentile" }\end{array}$ & $\begin{array}{l}\text { Lactuca } \\
\text { sattiva }\end{array}$ & 1 & 82 & 32 & 50 & 3.2 & $x$ & & & $\begin{array}{c}\mathrm{X} \\
(12)\end{array}$ & $x$ & $x$ & \\
\hline String bean & $\begin{array}{l}\text { Phaseolus } \\
\text { vulgaris }\end{array}$ & 2 & 90 & 11 & 79 & 1.9 & $x$ & & $\begin{array}{c}X \\
(120 \\
\mathrm{g})\end{array}$ & & $\mathrm{x}$ & $x$ & \\
\hline Zucchini & $\begin{array}{c}\text { Cucurbita } \\
\text { pepo }\end{array}$ & 4 & 99 & 11 & 88 & 3.9 & $x$ & & & $X(8)$ & $x$ & $x$ & \\
\hline Celery & $\begin{array}{c}\text { Apium } \\
\text { gravoelens }\end{array}$ & 0.7 & 96 & 11 & 85 & 4 & $x$ & & & $X(8)$ & $x$ & $x$ & \\
\hline $\begin{array}{r}\text { Tomato } \\
\text { (bunch) }\end{array}$ & $\begin{array}{l}\text { Lycopersicum } \\
\text { esculentum }\end{array}$ & 1 & 148 & 11 & 137 & 14.5 & $x$ & & & $X(4)$ & $x$ & $x$ & \\
\hline $\begin{array}{l}\text { Tomato } \\
\text { (table) }\end{array}$ & $\begin{array}{l}\text { Lycopersicum } \\
\text { esculentum }\end{array}$ & 1 & 148 & 11 & 137 & 10.6 & $x$ & & & $X(6)$ & $x$ & $x$ & \\
\hline Pepper & $\begin{array}{l}\text { Capsicum } \\
\text { annuum }\end{array}$ & 1.5 & 183 & 11 & 172 & 5.1 & $x$ & & & $X(6)$ & $x$ & $x$ & \\
\hline Eggplant & $\begin{array}{l}\text { Solanum } \\
\text { melongena }\end{array}$ & 1 & 163 & 11 & 152 & 7.7 & $x$ & & & $X(2)$ & $x$ & $x$ & \\
\hline String bean & $\begin{array}{c}\text { Phaseolus } \\
\text { vulgaris }\end{array}$ & 2 & 92 & 0 & 92 & 1.8 & $x$ & & $\begin{array}{c}X \\
(120 \\
g)\end{array}$ & & $x$ & $x$ & \\
\hline $\begin{array}{c}\text { Lettuce } \\
\text { “Cappuccia" }\end{array}$ & $\begin{array}{l}\text { Lactuca } \\
\text { sativa }\end{array}$ & 1.2 & 56 & 0 & 56 & 2.9 & $x$ & & & $\begin{array}{c}X \\
(12)\end{array}$ & $x$ & & $x$ \\
\hline $\begin{array}{l}\text { Chicory } \\
\text { "Catalogna" }\end{array}$ & $\begin{array}{c}\text { Cichorium } \\
\text { intybus }\end{array}$ & 0.5 & 51 & 0 & 51 & 10.6 & $x$ & & & $\begin{array}{c}X \\
(12)\end{array}$ & $x$ & & $x$ \\
\hline Celery & $\begin{array}{l}\text { Apium } \\
\text { gravoelens }\end{array}$ & 0.7 & 81 & 0 & 81 & 3.6 & $x$ & & & X (8) & $x$ & $x$ & \\
\hline $\begin{array}{l}\text { Chicory } \\
\text { "Treviso" } \\
\text { (Early) }\end{array}$ & $\begin{array}{l}\text { Cichorium } \\
\text { intybus }\end{array}$ & 1.3 & 107 & 29 & 78 & 1.6 & $x$ & & & $\begin{array}{c}\mathrm{X} \\
(12)\end{array}$ & $x$ & $x$ & \\
\hline $\begin{array}{l}\text { Savoy } \\
\text { cabbage } \\
\text { "Verza" }\end{array}$ & $\begin{array}{l}\text { Brassica } \\
\text { oleracea }\end{array}$ & 2 & 88 & 27 & 61 & 5.0 & $x$ & & & $\begin{array}{c}X \\
(12)\end{array}$ & $x$ & $x$ & \\
\hline
\end{tabular}




\subsection{Environmental and Economic Life Cycle Assessment}

The environmental and economic performances of the home garden were evaluated from a life cycle perspective by applying Life Cycle Assessment (LCA) and Life Cycle Costing (LCC) methods, respectively. The framework of LCA is regulated by the ISO 14040-14044 [56,57], which establishes a four-stage process: goal and scope definition, life cycle inventory, life cycle impact assessment, and interpretation. LCC also follows a four-stage framework based on the same ISO, although life cycle impact assessment is substituted by "cost aggregation", a step where the different costs of each life cycle stage are aggregated by category [58].

\subsubsection{Goal and Scope}

The purpose of the assessment was to quantify the environmental impacts and the economic cost of vegetables produced in home gardens. The functional unit of the assessment was $1 \mathrm{~kg}$ of harvested fresh vegetable at the consumption point. In this case, since the consumer was the gardener itself, the cradle-to-consumer approach can be considered as a cradle-to-fork one. The system boundaries, therefore, included all the stages of the life cycle of the vegetable from the extraction of raw materials to its consumption (Figure 2).

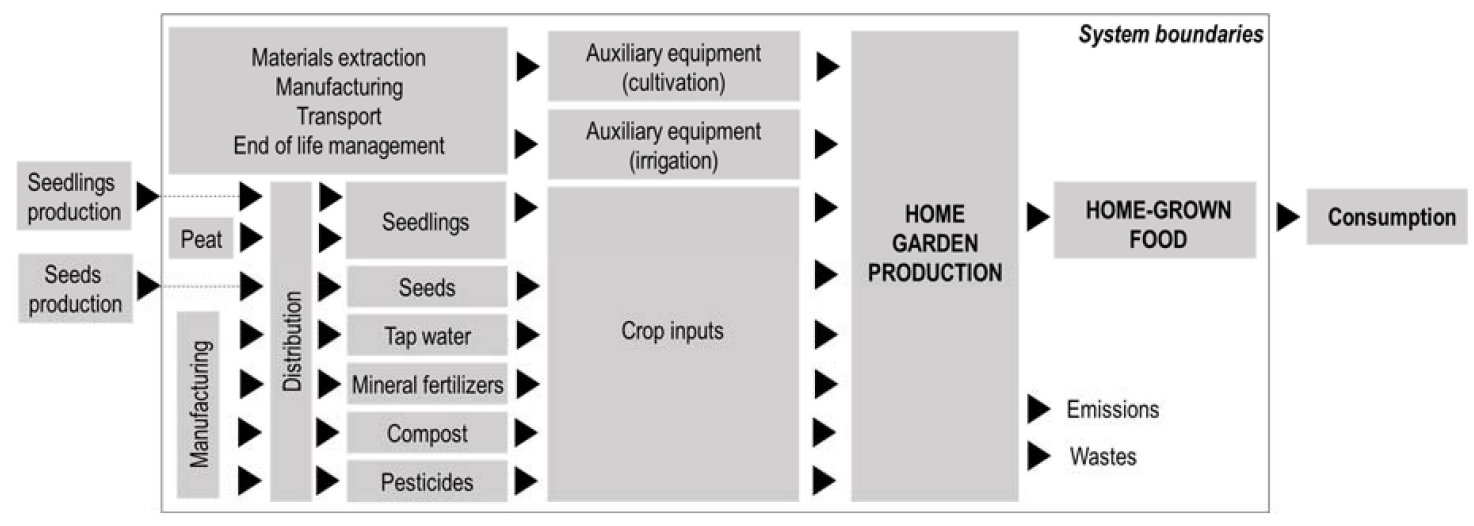

Figure 2. System boundaries and life cycle stages included in the life cycle assessment of vegetables production in home gardens.

\subsubsection{Life Cycle Inventory}

The life cycle inventory (LCI) for the crops under assessment was reported for the functional unit of $1 \mathrm{~kg}$ of harvested product (Table 2). The use of seeds, seedlings and fertilizers depended on the agricultural practices employed for each crop (as reported in Table 1). 
Table 2. Life cycle inventory of home gardening for a functional unit of $1 \mathrm{~kg}$ of harvested food product. Amount depends on crop period ( $\mathrm{T}$ )—including the number of cold days $\left(T_{c}\right.$, between $01 / 10$ and 30/04) and the number of warm days $\left(T_{w}\right.$, between 01/05 and 30/09), and crop yield ( $\left.n\right)(*$ Seeds, seedlings and fertilizers depend on the practices of each cycle, according to Table 1).

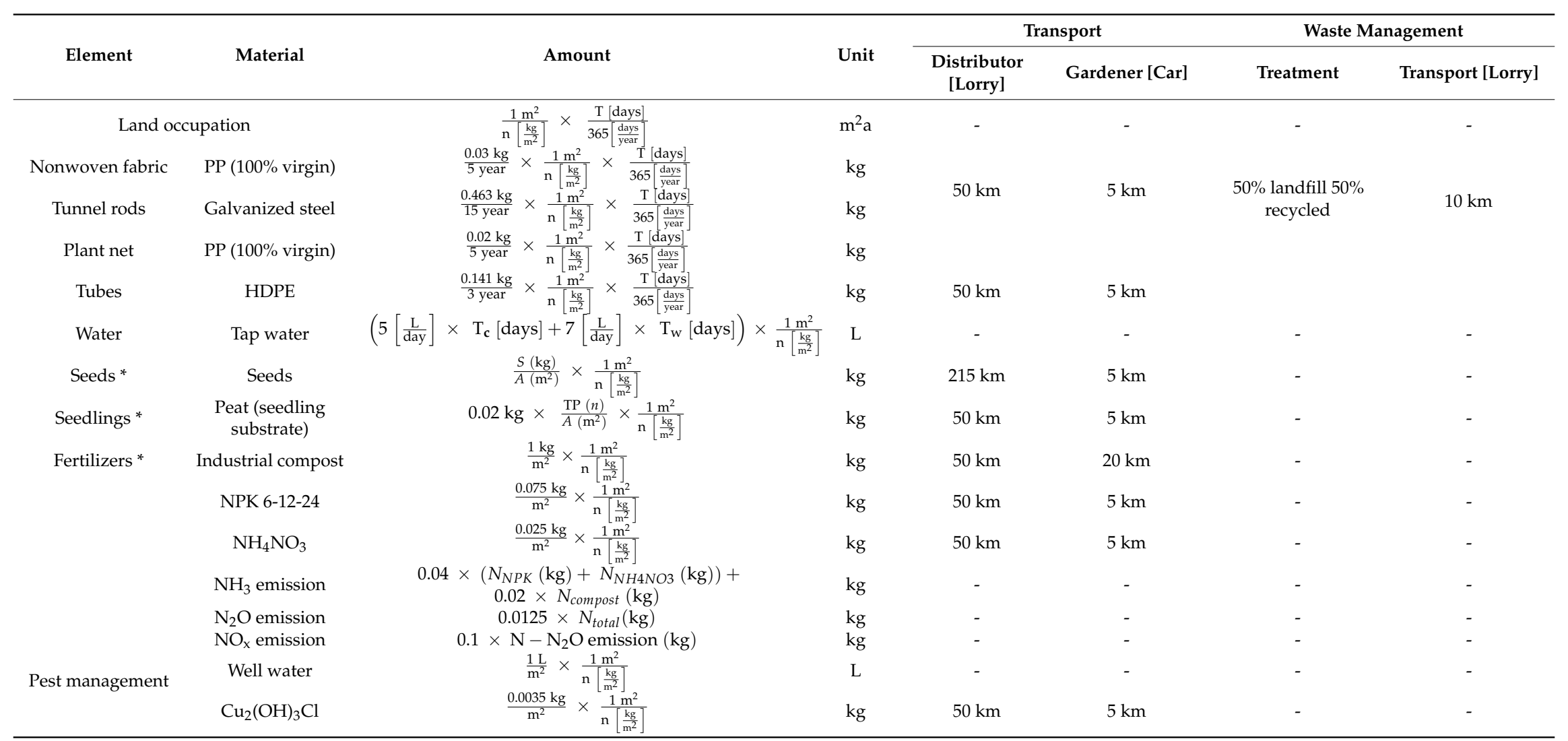


(a) Cultivation System and Auxiliary Equipment

This life cycle stage includes soil transformation and occupation, and the auxiliary equipment for cultivation and the irrigation system.

- Soil occupation: The implementation of the home garden implied the occupation of an unevenly built urban land for the entire crop period.

- Auxiliary equipment-Cultivation: Some winter crops required auxiliary equipment to protect them from adverse temperatures as well as a plant net to sustain proper growth. Peas and spinach were protected with non-woven fabric, which was raised above the ground with unused drawers to avoid growth hindrance. Lettuce and chard were grown in a tunnel made of non-woven fabric and supported by rods. The non-woven fabric was made of virgin polypropylene (density of $30 \mathrm{~g} \cdot \mathrm{m}^{-2}$ ) with lifespan of 5 years. The tunnel rods were made of galvanized steel, considering $95 \%$ recycled steel content. According to the design, the total amount of steel was of $463 \mathrm{~g} \cdot \mathrm{m}^{-2}$ (considering 3 rods per square metre- 0.75 linear metre) with lifespan of 15 years. A plant net, which was employed to sustain the growth of climbing species (i.e., peas), was made of virgin polypropylene (density of $20 \mathrm{~g} \cdot \mathrm{m}^{-2}$ ) with a lifespan of 5 years. While the gardener obtained these products at a local store $(5 \mathrm{~km})$ and transported them in a private car, the production site was assumed as regional $(50 \mathrm{~km})$ and the distribution transport was considered to be performed with a 7.5 ton-lorry.

- Auxiliary equipment-Irrigation: The irrigation system included irrigation tubes that supply tap water from the house. The tubes were made of high-density polyethylene and were distributed in the garden at a ratio of $2 \mathrm{~m} \cdot \mathrm{m}^{-2}$. They weighed $70.5 \mathrm{~g}$ per linear meter and had a lifespan of 3 years. Distribution distance was considered for a regional supply $(50 \mathrm{~km})$ with a 7.5 ton-lorry. The gardener bought the irrigation materials at a store $20 \mathrm{~km}$ away.

(b) Crop Inputs

This life cycle stage includes all the resources required for crop cultivation.

- Seeds: While seeds production was excluded from the system boundaries following a mass cut-off criterion [59], transportation was included. The distribution distance was of $215 \mathrm{~km}$, while the gardener acquired the seeds at the local market $(5 \mathrm{~km})$.

- Seedlings: The production of the seedlings was excluded due to lack of data and following a mass cut-off criterion. The life cycle data reported for seedlings included the production and transportation of $20 \mathrm{~g}$ of peat [60]. The distribution distance was assumed as regional $(50 \mathrm{~km})$ and the seedling were obtained at the local market $(5 \mathrm{~km})$.

- Water: Water consumption depended on the crop period length and the season. As mentioned in Section 2.1, a homogeneous irrigation rate between $5 \mathrm{~L} \cdot \mathrm{m}^{-2}$. day ${ }^{-1}$ and $7 \mathrm{~L} \cdot \mathrm{m}^{-2}$. day ${ }^{-1}$ of tap water was provided to the crops depending on the season. Irrigation rate was lower for cold days (01/10 to 30/04) than for warm days (01/05 to 30/09), in order to adapt to plant evapotranspiration. Irrigation was performed manually, implying that the gardener opened and closed the tap to provide the required amount of water without the need for auxiliary equipment to time and regulate the same.

- Organic fertilization: Industrial compost was used for organic mineralization. LCI for the manufacturing of industrial compost was obtained from the literature [61].

- Mineral fertilization: NPK 6-12-24 and ammonium nitrate were employed as mineral fertilizers (dosages indicated above).

- N air emissions from fertilization: Air emissions of different nitrogen components occurred due to the application of fertilizers, depending on the content of nitrogen and its form. According to Audsley [62] and Brentrup et al. [63], the $\mathrm{NH}_{3}$ volatilization from simple fertilizers was considered as $2 \%$ of the total nitrogen content (Equation (1)), and $4 \%$ for complex fertilizers 
(i.e., NPK) (Equation (2)). The $\mathrm{N}_{2} \mathrm{O}$ emissions represented $1.25 \%$ of the total nitrogen content (Equation (3)) and $\mathrm{NO}_{x}$ emissions were $10 \%$ of the $\mathrm{N}_{2} \mathrm{O}$ emissions (Equation (4)). The total amount in the three fertilizers depended on the nitrogen content and humidity. Data from producers were obtained for this calculation: $2.15 \%$ nitrogen content and $37 \%$ humidity for compost; $6 \%$ nitrogen content for NPK, and $34 \%$ nitrogen content for ammonium nitrate:

$$
\begin{gathered}
\mathrm{N}-\mathrm{NH}_{3} \text { emission }(\mathrm{kg})[N-\text { simple }]=0.02 \times N_{\text {total }}(\mathrm{kg}) \\
\mathrm{N}-\mathrm{NH}_{3} \text { emission }(\mathrm{kg})[N-N P K]=0.04 \times N_{\text {total }}(\mathrm{kg}) \\
\quad \mathrm{N}-\mathrm{N}_{2} \mathrm{O} \text { emission }(\mathrm{kg})=0.0125 \times N_{\text {total }}(\mathrm{kg}) \\
\mathrm{N}-\mathrm{NO}_{\mathrm{x}} \text { emission }(\mathrm{kg})=0.1 \times \mathrm{N}-\mathrm{N}_{2} \mathrm{O} \text { emission }(\mathrm{kg})
\end{gathered}
$$

- N lixiviates were excluded from the system boundaries as no measured data were available.

- Pest management: Pest control treatments were performed only once on crops, a few days after transplanting using $25 \mathrm{~L}$ of copper oxychloride $\left(\mathrm{Cu}_{2}(\mathrm{OH})_{3} \mathrm{Cl}\right)$ at a concentration of $3.5 \mathrm{~g} \cdot \mathrm{L}^{-1}$ (in well water).

(c) Waste Management

Waste management depended on the type of produced waste. A waste scenario was defined as follows for elements of auxiliary equipment: $50 \%$ recycled, including the transportation to the local recycling plant $(10 \mathrm{~km})$, and $50 \%$ final disposal in an incinerator, according to waste management facilities available in the area [64].

(d) Costs

Cost data for each element was collected to account for the total cost of the life cycle. Data for the purchased elements (e.g., nonwoven fabric, seeds) were obtained from specialized sellers in the study area. Due to the variability of seedlings' price in the market, an average from three different suppliers was used in this assessment. Tap water cost was obtained from the local water provider (Gruppo Hera). Distribution costs were considered as included in the product price when obtained by the gardener. The gardener's transport costs were estimated according to the vehicle model, the fuel consumption rate and the fuel price. Appendix A (Table A1, Table A2 and Table A3) shows the unitary cost data of different elements employed in this LCC.

\subsubsection{Life Cycle Impact Assessment}

Once the LCI was completed for each crop, the impact assessment phase of the LCA was performed by employing the software, Simapro 8.3.0 [65]. To classify and characterize each flow, as mandatory steps of the ISO 14040-44 [57,66], the ReCiPe method [67] was chosen. Midpoint characterization factors and a hierarchical perspective were used as recommended by global guidelines [59]. The indicators included in this assessment were: climate change (CC, $\mathrm{kg} \mathrm{CO}$ eq.), ozone depletion (OD, kg CFC-11 eq.), terrestrial acidification (TA, $\mathrm{kg} \mathrm{SO} \mathrm{S}_{2}$ eq.), freshwater eutrophication (FEU, kg P eq.), marine eutrophication (MEU, $\mathrm{kg} \mathrm{N}$ eq.), human toxicity (HT, $\mathrm{kg}$ 1.4-DB eq.), photochemical oxidant formation ( $\mathrm{POF}, \mathrm{kg}$ NMVOC), particulate matter formation (PMF, $\mathrm{kg} \mathrm{PM}_{10}$ eq.), terrestrial ecotoxicity (TET, kg 1,4-DB eq.), freshwater ecotoxicity (FET, kg 1.4-DB eq.), marine ecotoxicity (MET, $\mathrm{kg}$ 1.4-DB eq.), ionising radiation ( $\mathrm{IR}, \mathrm{kBq} \mathrm{U}_{235}$ eq.), agricultural land occupation (ALO, $\mathrm{m}^{2} \mathrm{a}$ ), urban land occupation (ULO, $\mathrm{m}^{2} \mathrm{a}$ ), natural land transformation (NLT, $\mathrm{m}^{2}$ ), water depletion (WD, $\mathrm{m}^{3}$ ), metal depletion (MD, kg Fe eq.), and fossil depletion (FD, kg oil eq.).

\subsubsection{Life Cycle Costing}

For life cycle costing, the costs of different elements were aggregated by life cycle stages. The total cost was compared to the price in the market of each product. Three market prices were considered 
for the assessment: Italian market (data from national statistics [68]), bio market (data from a farmers' association [69]), and the local market (data from a local farmer).

\subsubsection{Data Quality and Geographical Adaptation}

LCI data of the home-garden products were collected from the cultivation system of the case study (primary data). LCI data regarding material extraction, processing, transportation and electricity generation were obtained from the ecoinvent database 3.0 [70], while literature data were used for compost production [61] (background data). When background data was employed, the datasets were adapted to the geographical context of the case study of Padua (Italy), thereby indicating the consumption of Italian resources (e.g., natural gas, electricity, water) and of materials produced in their origin markets. Background data was adapted to the geographical context of the study area. In this sense, the consumption of local resources was allocated to Italian resources and the consumption of energy adapted to the Italian market.

\subsection{Food Security Potential}

The food security potential was evaluated as the capacity of the garden to satisfy the vegetables requirements of the gardener, according to consumption and health recommendations. As multiple statistics with a different level of detail can be employed as reference, food security was evaluated for three baseline scenarios:

- HEALTH: The World Health Organization (WHO) indicates that a healthy diet contains, "At least $400 \mathrm{~g}$ (five portions) of fruits and vegetables a day", excluding potatoes, sweet potatoes, cassava and other starchy roots [71].

- SUPPLY: The Food Balance Sheets of the Food and Agriculture Organization of the United Nations (FAO/UN) indicated that food supply in 2013 in Italy for vegetables was of $123.13 \mathrm{~kg} \cdot$ year $^{-1} \cdot \mathrm{p}^{-1}[72]$.

- CONSUMPTION: The average Italian consumption, according to data from the Italian National Food Consumption Survey (INRAN-SCAI 205-06) [73], accounted for the daily average consumption of vegetables as $211.2 \mathrm{~g} \cdot$ day $^{-1}$ (including $43.1 \mathrm{~g}$ of leafy vegetables, $41.9 \mathrm{~g}$ of tomatoes and 30.9 of other fruiting vegetables).

\section{Results}

This section displays the results of assessment of urban food production in the home garden.

\subsection{Environmental Impact of a Home Garden}

The environmental impact for different indicators of the home garden is shown in Table 3; they include impact per product (i.e., home-grown food), impact per area, and the total impact of garden activity. The impact and causes of each indicator is described below.

Climate change: The average climate change impact of home-grown products was $0.268 \mathrm{~kg} \mathrm{CO}_{2}$ eq $\cdot \mathrm{kg}^{-1}$. The contribution to climate change was associated with the emissions of carbon dioxide $\left(\mathrm{CO}_{2}\right)$, dinitrogen monoxide $\left(\mathrm{N}_{2} \mathrm{O}\right)$, and methane $\left(\mathrm{CH}_{4}\right)$. Carbon dioxide originated as direct emission during the municipal solid waste (MSW) collection service (organic fertilization) and as indirect emission in the consumption of tap water and the production process of ammonium nitrate, which required electricity; non-renewable energy sources were also employed in the Italian electricity mix (i.e., hard coal, natural gas and oil). Dinitrogen monoxide was mainly emitted in the production process of ammonium nitrate and during the MSW collection service. Methane emission occurred mainly as indirect emission during the landfill process of the MSW that was discarded during industrial compost production. 
Table 3. Environmental impact results per home-grown food $[\mathrm{kg}]$, per area $\left[\mathrm{m}^{2}\right]$, and for the entire garden.

\begin{tabular}{|c|c|c|c|c|}
\hline Indicator & Unit & Home-Grown Food & Area & Garden \\
\hline Climate change (CC) & $\mathrm{kg} \mathrm{CO}_{2} \mathrm{eq}$ & $2.68 \times 10^{-1}$ & 1.32 & $4.34 \times 10^{1}$ \\
\hline Ozone depletion (OD) & kg CFC-11 eq & $1.38 \times 10^{-8}$ & $6.80 \times 10^{-8}$ & $2.24 \times 10^{-6}$ \\
\hline Terrestrial acidification (TA) & $\mathrm{kg} \mathrm{SO}_{2}$ eq & $1.43 \times 10^{-3}$ & $7.03 \times 10^{-3}$ & $2.32 \times 10^{-1}$ \\
\hline Freshwater eutrophication (FEU) & $\mathrm{kg} \mathrm{Peq}$ & $8.68 \times 10^{-5}$ & $4.27 \times 10^{-4}$ & $1.40 \times 10^{-2}$ \\
\hline Marine eutrophication (MEU) & $\mathrm{kg} \mathrm{N} \mathrm{eq}$ & $3.66 \times 10^{-4}$ & $1.80 \times 10^{-3}$ & $5.92 \times 10^{-2}$ \\
\hline Human toxicity (HT) & kg 1.4-DB eq & $2.25 \times 10^{-1}$ & 1.10 & $3.64 \times 10^{1}$ \\
\hline Photochemical oxidant formation (POF) & kg NMVOC & $8.72 \times 10^{-4}$ & $4.29 \times 10^{-3}$ & $1.41 \times 10^{-1}$ \\
\hline Particulate matter formation (PMF) & $\mathrm{kg} \mathrm{PM}_{10} \mathrm{eq}$ & $4.30 \times 10^{-4}$ & $2.11 \times 10^{-3}$ & $6.96 \times 10^{-2}$ \\
\hline Terrestrial ecotoxicity (TET) & $\mathrm{kg} 1.4-\mathrm{DB}$ eq & $3.52 \times 10^{-5}$ & $1.73 \times 10^{-4}$ & $5.69 \times 10^{-3}$ \\
\hline Freshwater ecotoxicity (FET) & kg 1.4-DB eq & $2.17 \times 10^{-2}$ & $1.07 \times 10^{-1}$ & 3.51 \\
\hline Marine ecotoxicity (MET) & $\mathrm{kg} 1.4-\mathrm{DB}$ eq & $1.91 \times 10^{-2}$ & $9.40 \times 10^{-2}$ & 3.09 \\
\hline Ionizing radiaton (IR) & $\mathrm{kBq}_{235} \mathrm{eq}$ & $1.77 \times 10^{-2}$ & $8.70 \times 10^{-2}$ & 2.86 \\
\hline Agricultural land occupation (ALO) & $\mathrm{m}^{2} \mathrm{a}$ & $5.66 \times 10^{-3}$ & $2.78 \times 10^{-2}$ & $9.16 \times 10^{-1}$ \\
\hline Urban land occupation (ULO) & $\mathrm{m}^{2} \mathrm{a}$ & $7.41 \times 10^{-2}$ & $3.64 \times 10^{-1}$ & $1.20 \times 10^{1}$ \\
\hline Natural land transformation (NLT) & $\mathrm{m}^{2}$ & $3.84 \times 10^{-5}$ & $1.88 \times 10^{-4}$ & $6.21 \times 10^{-3}$ \\
\hline Water depletion (WD) & $\mathrm{m}^{3}$ & $5.94 \times 10^{-1}$ & 2.92 & $9.62 \times 10^{1}$ \\
\hline Metal depletion (MD) & $\mathrm{kg} \mathrm{Fe} \mathrm{eq}$ & $4.08 \times 10^{-2}$ & $2.01 \times 10^{-1}$ & 6.61 \\
\hline Fossil depletion (FD) & $\mathrm{kg}$ oil eq & $5.09 \times 10^{-2}$ & $2.50 \times 10^{-1}$ & 8.23 \\
\hline
\end{tabular}

Ozone depletion: Ozone depletion impact was of $1.38 \times 10^{-8} \mathrm{~kg}$ CFC-11 eq. $\mathrm{kg}^{-1}$ home-grown food, on an average. Ozone depletion was caused by methane emissions in the form of bromotrifluoromethane (Halon 1301) and bromochlorodifluoromethane (Halon 1211) from tap water consumption, ammonium nitrate production, and industrial compost use.

Terrestrial acidification: The contribution to terrestrial acidification was, on an average, $1.43 \times$ $10^{-3} \mathrm{~kg} \mathrm{SO}{ }_{2}$ eq. $\cdot \mathrm{kg}^{-1}$ home-grown food. Sulfur oxide $\left(\mathrm{SO}_{2}\right)$, ammonia $\left(\mathrm{NH}_{3}\right)$ and nitrogen oxides $\left(\mathrm{NO}_{\mathrm{x}}\right)$ emissions were the main contributors to terrestrial acidification. These emissions were produced during tap water supply (sulfur dioxide, nitrogen oxides), ammonium nitrate production (ammonia), compost production (ammonia, nitrogen oxides), $\mathrm{N}$-fertilizers application (ammonia), and pesticide production (sulfur oxide).

Freshwater eutrophication: The impact on freshwater eutrophication was $8.68 \times 10^{-5} \mathrm{~kg} \mathrm{P}$ eq. $\cdot \mathrm{kg}^{-1}$, on an average. Sulfate emissions to water were produced in the pest management stage, due to lixiviates in mining operations to obtain copper.

Marine eutrophication: The contribution to terrestrial acidification was, on an average, $3.66 \times 10^{-4} \mathrm{~kg} \mathrm{~N}$ eq. $\cdot \mathrm{kg}^{-1}$ home-grown food. Emissions of ammonium $\left(\mathrm{NH}_{4}{ }^{+}\right)$, nitrogen ( $\mathrm{N}$, organic) and nitrate $\left(\mathrm{NO}_{3}\right)$ to water were mainly produced as lixiviates in the landfilling of discarded MSW from industrial compost production. Nitrogen oxides and ammonia emissions to air resulted from electricity consumption in the tap water system, from the production of ammonium nitrate (nitric acid production) and industrial compost (MSW collection, electricity consumption), and direct emissions of applying N-fertilizers.

Human toxicity: The ozone depletion impact was of $2.25 \times 10^{-1} \mathrm{~kg} 1.4-\mathrm{DB}$ eq. $\mathrm{kg}^{-1}$ home-grown food, on an average. Manganese emissions to water were produced as lixiviates during mining operations to obtain copper (pest management) and the landfilling of discarded MSW in the industrial compost process (organic fertilization).

Photochemical oxidant formation: The average photochemical oxidant formation of home-grown products was of $8.72 \times 10^{-4} \mathrm{~kg} \mathrm{NMVOC} \cdot \mathrm{kg}^{-1}$. $\mathrm{NO}_{\mathrm{x}}, \mathrm{NMVOC}, \mathrm{SO}_{2}$ and $\mathrm{CH}_{4}$ emissions to air were the main contributors, mainly due to the electricity consumed along the life cycle, the emissions of transport use (particularly during MSW collection) and the landfilling of MSW (compost production).

Particulate matter formation: The contribution to particulate matter formation was, on an average, $8.72 \times 10^{-4} \mathrm{~kg} \mathrm{PM} 10$ eq. $\mathrm{kg}^{-1}$ home-grown food. The impact was mainly caused by $\mathrm{NO}_{x}, \mathrm{SO}_{2}, \mathrm{PM}_{2.5}$, $\mathrm{NH}_{3}$ and particulates emissions to air. A large share of these emissions occurred during the production 
stage of the electricity consumed in the tap water service, direct emissions from the MSW collection service in compost production, pesticides production, and direct emissions when applying $\mathrm{N}$-fertilizers.

Terrestrial ecotoxicity: The terrestrial ecotoxicty impact was of $3.52 \times 10^{-5} \mathrm{~kg} 1.4$-DB eq. $\cdot \mathrm{kg}^{-1}$ home-grown food, on average. The emissions contributing to this impact were copper, zinc and vanadium emissions to air, cypermethrin and aldicarb emissions to soil, and bromine emissions to water during the stages of tap water consumption, organic fertilizers, and mineral fertilizers. Beyond these, chlorine emissions to water during the treatment of tap water were the second-most impacting ones.

Freshwater ecotoxicity (FET): The average freshwater ecotoxicity of home-grown products was of $2.17 \times 10^{-2} \mathrm{~kg} 1.4$-DB eq. $\mathrm{kg}^{-1}$. The largest contributors to this impact were emissions to water of copper (compost production), nickel (compost production and tap water consumption), zinc (compost production and pesticides production), and manganese (pesticides production).

Marine ecotoxicity (MET): The contribution to marine ecotoxicity was, on an average, $1.91 \times$ $10^{-2} \mathrm{~kg}$ 1.4-DB eq. $\mathrm{kg}^{-1}$ home-grown food. The same emissions to water as of FET were the major contributors.

Ionizing radiation (IR): The impact of ionizing radiation was $1.77 \times 10^{-2} \mathrm{~kg} \mathrm{U}_{235} \mathrm{eq} \cdot \mathrm{kg}^{-1}$, on average. Emissions of Carbon-14 and Radon-222 to air were produced in nuclear plants feeding the electricity market in Italy.

Agricultural land occupation (ALO): The agricultural land occupation was $5.66 \times 10^{-3} \mathrm{~m}^{2} \mathrm{a} \cdot \mathrm{kg}^{-1}$ home-grown food, on average. The occupation of forest land occurred in the electricity production in Italy, mainly in two processes: wood employed in biomass co-generation plants and wood used in mine infrastructure for hard coal extraction for electricity production.

Urban land occupation (ULO): The average urban land occupation of home-grown products was of $7.41 \times 10^{-2} \mathrm{~m}^{2} \mathrm{a} \cdot \mathrm{kg}^{-1}$. The direct occupation of the garden itself was the main contributor to this impact category.

Natural land transformation (NLT): The contribution to natural land transformations was, on average, $3.84 \times 10^{-5} \mathrm{~m}^{2} \cdot \mathrm{kg}^{-1}$ home-grown food. Transformation of sea and ocean, forest and extensive forest land uses were caused by electricity production, according to the Italian mix, particularly during natural gas and heavy fuel oil extraction procedures.

Water depletion (WD): The average depletion of water resources for home-grown products was of $5.95 \times 10^{-1} \mathrm{~m}^{3} \cdot \mathrm{kg}^{-1}$. Water was mainly directly consumed for crop irrigation. However, indirect consumption of water occurred in the processing of different fertilizers, particularly industrial compost, due to the use of electricity and water employed for turbine use.

Metal depletion (MD): Metal depletion was $4.08 \times 10^{-2} \mathrm{~kg} \mathrm{Fe} \mathrm{eq.} \cdot \mathrm{kg}^{-1}$, on average. Most of the metal depletion was associated with the copper consumed for producing the pesticide (copper sulfate). Copper employed in the water supply network was also a relevant contribution.

Fossil depletion (FD): Fossil depletion impact was $5.09 \times 10^{-2} \mathrm{~kg}$ oil eq. $\cdot \mathrm{kg}^{-1}$ home-grown food, on average. Depletion of oil, natural gas and hard coal occurred in energy-consuming activities of the life cycle-electricity and fuels.

\section{Normalized Values for the European Region}

When the midpoint indicators were normalized for the European region, the most relevant indicator categories rose. Marine ecotoxicity $(40.9 \%)$ and freshwater ecotoxicity $(36.7 \%)$ had the largest contributions. In the second tier, human toxicity $(6.6 \%)$, nature land transformation $(4.3 \%)$, freshwater eutrophization $(3.9 \%)$ and urban land occupation $(3.2 \%)$ had relevant contribution. The indicators that showed a lower relevance were ozone depletion, terrestrial ecotoxicity, ionizing radiation, agricultural land occupation and water depletion, with contributions lower than $0.1 \%$. The average contribution of the 18 indicators to the normalized value is shown in Appendix B (Figure A1). 


\subsection{Contribution of Life Cycle Stages}

Figure 3 shows the contribution of the different life cycle stages to each environmental indicator. The highest contributing stages were fertilization (both organic and mineral), tap water consumption, and pesticides.

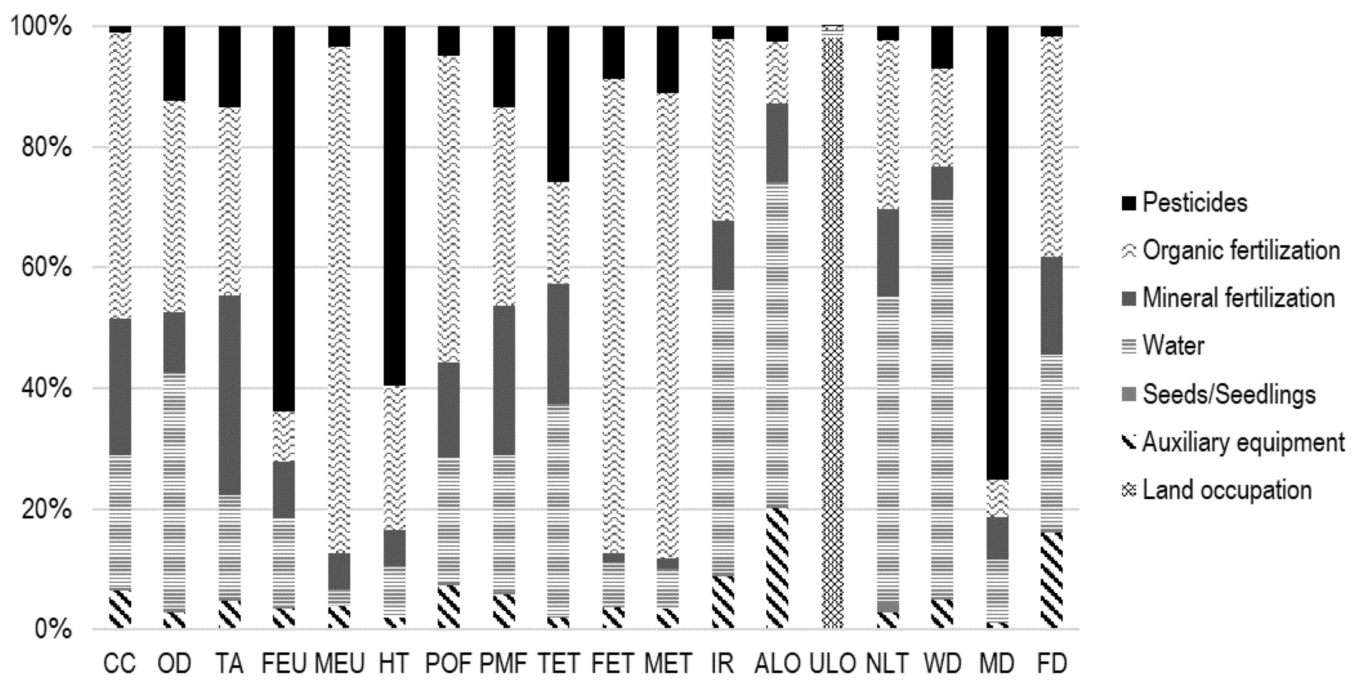

Figure 3. Contribution of the different life cycle stages to environmental impact indicators. The included indicators are climate change (CC, $\mathrm{kg} \mathrm{CO}_{2}$ eq.), ozone depletion (OD, $\mathrm{kg} C \mathrm{CF}-11$ eq.), terrestrial acidification (TA, $\mathrm{kg} \mathrm{SO}_{2}$ eq.), freshwater eutrophication (FEU, $\mathrm{kg}$ P eq.), marine eutrophication (MEU, $\mathrm{kg} \mathrm{N}$ eq.), human toxicity (HT, kg 1.4-DB eq.), photochemical oxidant formation (POF, kg NMVOC), particulate matter formation (PMF, $\mathrm{kg} \mathrm{PM}_{10}$ eq.), terrestrial ecotoxicity (TET, $\mathrm{kg}$ 1.4-DB eq.), freshwater ecotoxicity (FET, kg 1.4-DB eq.), marine ecotoxicity (MET, kg 1.4-DB eq.), ionising radiation (IR, $\mathrm{kBq}$ $\mathrm{U}_{235}$ eq.), agricultural land occupation ( $\mathrm{ALO}, \mathrm{m}^{2} \mathrm{a}$ ), urban land occupation (ULO, $\mathrm{m}^{2} \mathrm{a}$ ), natural land transformation (NLT, $\mathrm{m}^{2}$ ), water depletion (WD, $\mathrm{m}^{3}$ ), metal depletion (MD, kg Fe eq.), and fossil depletion (FD, kg oil eq.).

Organic fertilization: Compost production, transportation and application contributed to between $0.5 \%$ to $83.9 \%$ of the environmental impact, $34 \%$ on average. This was the largest contributing stage for MEU (83.9\%), FET (78.6\%), MET (77.0\%), POF (50.9\%), CC (47\%), PMF (32.9\%) and FD (36.5\%).

Water: The consumption of tap water was the second most contributing element of the life cycle (25.2\%, on average), with contributions to the indicators ranging from 1.1 to $66.0 \%$. Water had the largest impact in WD (66.0\%), ALO (53.6\%), NLT (51.0\%), IR (46.7\%), OD (39.1), TET (35.2\%) and MD (10.4\%).

Mineral fertilization: The mineral fertilizers life cycle stage contributed to the impact categories between $0.22 \%$ to $33.0 \%$ (12.1\%, on average). Mineral fertilizers had the largest contribution to TA $(33.0 \%)$ and was the second-most relevant stage in the indicators of CC $(22.7 \%)$ and PMF $(24.9 \%)$.

Pesticides: The contribution of pesticides to the life cycle impact varied from 0.1 to $75.2 \%$, depending on the indicator (average contribution of 17.2\%). Being the major contributor to MD $(75.2 \%)$, FEU (63.8\%) and HT (59.6\%), this stage also had a relevant impact on TET (25.9\%).

Other life cycle stages: Auxiliary equipment had a relevant contribution to the ALO (20.2\%) and FD (16.1\%) indicators, although the average contribution was 5.6\%. Land occupation by the home garden contributed to the ULO $(98 \%)$ and FD $(5.5 \%)$ categories, with no attributed impact to the rest of the indicators. The production of seeds, production of substrate for seedlings, and their transportation had the lowest contribution to the overall impact $(<1.6 \%$ for all the categories $-0.4 \%$ on average). 


\subsection{Home Garden Design: Crop Impacts}

When evaluating each crop individually, the environmental impact assessment showed a common pattern for different indicators, as crop management practices were mostly homogeneous (apart from some protected crops and some crops without mineral fertilization, e.g., crop rotations). For all the indicators, the lowest impact was shown for spring-summer crops of chicory, tomato (both bunch and table) and eggplant, as well as a winter crop of chard. The most impacting ones were a summer-autumn crop of chicory, a winter crop of peas and the two spring-summer crops of string beans. Figure $4 \mathrm{a}$ shows the environmental impact of the 21 crops under assessment for climate change, as an example of this trend.

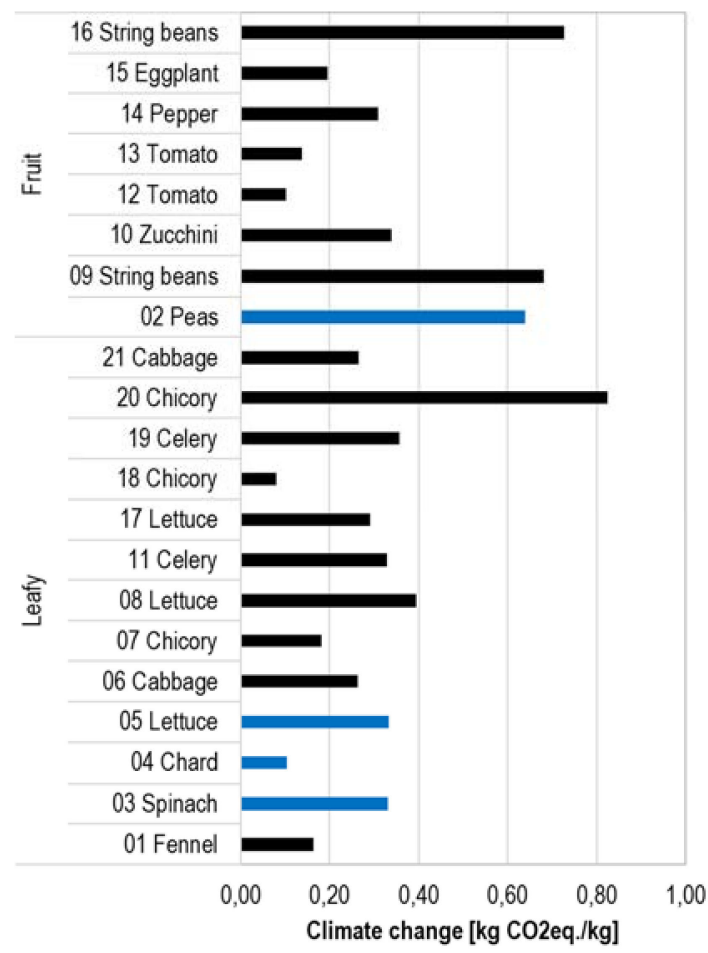

(a)
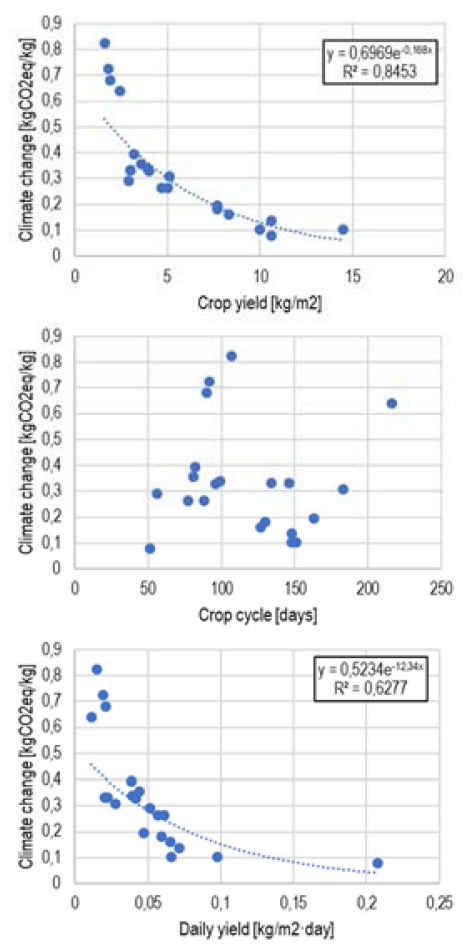

(b)

Figure 4. Climate change impact of home garden crops: (a) Results for the 21 crops under assessment, including unprotected crops (black) and protected crops (blue); and (b) Correlation between climate change impact and crop yield, crop cycle, and daily yield. Crops can be identified according to the values of crop yield and crop cycle from Table 1.

The correlation between the environmental impact and the agronomical characteristics of each crop was evaluated to identify the main factors determining environmental impact. Crop yield and crop cycle were tested for all the indicators. While crop yield resulted in a determining factor for all the indicators with a high correlation $\left(R^{2}=0.77-0.91\right)$, crop cycle showed no correlation nor pattern. When crop yield and crop cycle were combined in a daily crop yield parameter, environmental impacts showed moderate correlation for all the indicators $\left(R^{2}=0.52-0.72\right)$. Figure $4 \mathrm{~b}$ displays the correlation assessment for climate change.

Table 4 includes the environmental impact results (average, minimum and maximum) for the different indicators by type of vegetable: leafy (fennel, spinach, chard, lettuce cabbage, chicory, celery) and fruit (peas, string beans, zucchini, tomato, pepper, eggplant). On average, leafy vegetables had a $30 \%$ lower environmental impact than fruit vegetables. 
Table 4. Average, minimum, and maximum environmental impact value for each LCIA indicator, by type of vegetable (leafy, fruit).

\begin{tabular}{|c|c|c|c|c|c|c|c|}
\hline \multirow{2}{*}{ LCIA } & \multirow{2}{*}{ Unit } & \multicolumn{3}{|c|}{ Leafy } & \multicolumn{3}{|c|}{ Fruit } \\
\hline & & AVG & MIN & MAX & AVG & MIN & MAX \\
\hline $\mathrm{CC}$ & $\mathrm{kgCO}_{2} \mathrm{eq}$ & $3.01 \times 10^{-1}$ & $7.92 \times 10^{-2}$ & $8.24 \times 10^{-1}$ & $4.43 \times 10^{-1}$ & $7.92 \times 10^{-2}$ & $7.26 \times 10^{-1}$ \\
\hline OD & $\mathrm{kg} \mathrm{CFC}-11 \mathrm{eq}$ & $1.55 \times 10^{-8}$ & $4.41 \times 10^{-9}$ & $4.05 \times 10^{-8}$ & $2.27 \times 10^{-8}$ & $4.41 \times 10^{-9}$ & $3.57 \times 10^{-8}$ \\
\hline $\mathrm{TA}$ & $\mathrm{kg} \mathrm{SO}_{2} \mathrm{eq}$ & $1.58 \times 10^{-3}$ & $3.73 \times 10^{-4}$ & $4.51 \times 10^{-3}$ & $2.38 \times 10^{-3}$ & $3.73 \times 10^{-4}$ & $3.98 \times 10^{-3}$ \\
\hline FEU & $\mathrm{kg} \mathrm{P}$ eq & $1.03 \times 10^{-4}$ & $3.31 \times 10^{-5}$ & $2.64 \times 10^{-4}$ & $1.40 \times 10^{-4}$ & $3.13 \times 10^{-5}$ & $2.33 \times 10^{-4}$ \\
\hline MEU & $\mathrm{kg} \mathrm{N}$ eq & $4.51 \times 10^{-4}$ & $1.55 \times 10^{-4}$ & $1.13 \times 10^{-3}$ & $5.85 \times 10^{-4}$ & $1.27 \times 10^{-4}$ & $9.99 \times 10^{-4}$ \\
\hline $\mathrm{HT}$ & $\mathrm{kg} 1.4-\mathrm{DB}$ eq & $2.74 \times 10^{-1}$ & $9.30 \times 10^{-2}$ & $6.87 \times 10^{-1}$ & $3.60 \times 10^{-1}$ & $7.90 \times 10^{-2}$ & $6.09 \times 10^{-1}$ \\
\hline POF & kg NMVOC & $1.00 \times 10^{-3}$ & $2.90 \times 10^{-4}$ & $2.65 \times 10^{-3}$ & $1.43 \times 10^{-3}$ & $2.90 \times 10^{-4}$ & $2.33 \times 10^{-3}$ \\
\hline PMF & $\mathrm{kg} \mathrm{PM}_{10} \mathrm{eq}$ & $4.79 \times 10^{-4}$ & $1.23 \times 10^{-4}$ & $1.32 \times 10^{-3}$ & $7.10 \times 10^{-4}$ & $1.23 \times 10^{-4}$ & $1.17 \times 10^{-3}$ \\
\hline TET & kg 1.4-DB eq & $3.88 \times 10^{-5}$ & $9.95 \times 10^{-6}$ & $1.06 \times 10^{-4}$ & $5.82 \times 10^{-5}$ & $9.95 \times 10^{-6}$ & $9.33 \times 10^{-5}$ \\
\hline FET & $\mathrm{kg} 1.4-\mathrm{DB}$ eq & $2.67 \times 10^{-2}$ & $9.40 \times 10^{-3}$ & $6.57 \times 10^{-2}$ & $3.46 \times 10^{-2}$ & $7.55 \times 10^{-3}$ & $5.83 \times 10^{-2}$ \\
\hline MET & $\mathrm{kg} 1.4-\mathrm{DB}$ eq & $2.36 \times 10^{-2}$ & $8.31 \times 10^{-3}$ & $5.81 \times 10^{-2}$ & $3.05 \times 10^{-2}$ & $6.64 \times 10^{-3}$ & $5.15 \times 10^{-2}$ \\
\hline IR & $\mathrm{kBq} \mathrm{U}_{235} \mathrm{eq}$ & $1.93 \times 10^{-2}$ & $5.04 \times 10^{-3}$ & $5.10 \times 10^{-2}$ & $2.92 \times 10^{-2}$ & $5.04 \times 10^{-3}$ & $4.62 \times 10^{-2}$ \\
\hline ALO & $\mathrm{m}^{2} \mathrm{a}$ & $5.84 \times 10^{-3}$ & $1.24 \times 10^{-3}$ & $1.57 \times 10^{-2}$ & $9.44 \times 10^{-3}$ & $1.24 \times 10^{-3}$ & $1.66 \times 10^{-2}$ \\
\hline ULO & $\mathrm{m}^{2} \mathrm{a}$ & $7.60 \times 10^{-2}$ & $1.44 \times 10^{-2}$ & $1.96 \times 10^{-1}$ & $1.20 \times 10^{-1}$ & $1.44 \times 10^{-2}$ & $2.56 \times 10^{-1}$ \\
\hline NLT & $\mathrm{m}^{2}$ & $4.16 \times 10^{-5}$ & $1.09 \times 10^{-5}$ & $1.12 \times 10^{-4}$ & $6.33 \times 10^{-5}$ & $1.09 \times 10^{-5}$ & $9.95 \times 10^{-5}$ \\
\hline WD & $\mathrm{m}^{3}$ & $6.33 \times 10^{-1}$ & $1.59 \times 10^{-1}$ & 1.64 & $9.82 \times 10^{-1}$ & $1.59 \times 10^{-1}$ & 1.63 \\
\hline MD & $\mathrm{kg} \mathrm{Fe}$ eq & $4.96 \times 10^{-2}$ & $1.65 \times 10^{-2}$ & $1.24 \times 10^{-1}$ & $6.55 \times 10^{-2}$ & $1.44 \times 10^{-2}$ & $1.10 \times 10^{-1}$ \\
\hline FD & $\mathrm{kg}$ oil eq & $5.62 \times 10^{-2}$ & $1.47 \times 10^{-2}$ & $1.51 \times 10^{-1}$ & $8.39 \times 10^{-2}$ & $1.47 \times 10^{-2}$ & $1.32 \times 10^{-1}$ \\
\hline
\end{tabular}

\subsection{Economic Cost and Eco-Efficiency Analysis}

Life cycle costing (LCC) accounted for the overall costs of the home garden vegetables. The average cost of the home-grown vegetables was of $1.57 € \cdot \mathrm{kg}^{-1}$, ranging from $0.46 €$ to $3.56 €$. The different life cycle stages contributed in a different manner. On average, seedlings were the most-expensive element of the life cycle $(45 \%)$, followed by the compost employed as organic fertilizer $(27 \%)$ and tap water for irrigation $(17 \%)$. Mineral fertilizers $(6 \%)$, pesticides $(3 \%)$ and elements of the auxiliary equipment $(2 \%)$ were the cheapest elements. When comparing the total cost with the market prices (Italian market, bio market and local market), home-grown vegetables were cheaper than market vegetables, apart from three crops-the two cycles of celery and the chicory variety 'Treviso' (Appendix C, Figure A2). Therefore, the home garden offered economic savings due to food self-production to the gardener.

The relationship between the environmental impact and the economic cost was analyzed through eco-efficiency charts, to identify best crops and desired trends. The analysis unveiled three areas of the chart: eco-efficient crops (A), high-impact low-cost crops (B) and low-impact high-cost crops (C). The same pattern was found for the different indicators under assessment. Figure 5 illustrates this pattern for CC, WD, HT and FET.

Eco-efficiency crops (A) included a variety of leafy vegetables and tomatoes, which were the crops performing best as fruit vegetables. In area $\mathrm{B}$, there were crops with a low-crop yield: chicory, string beans and peas. The area $C$ included some fruit vegetables (pepper, zucchini, eggplant) and leafy vegetables (celery, lettuce) mainly due to the high cost of seedlings. The desirable trend (indicated with grey arrows in Figure 5) would be to decrease the impact of B-area crops as well as the price of $\mathrm{C}$-area crops, while improving crop performance of certain vegetables and finding alternatives to expensive seedlings. 

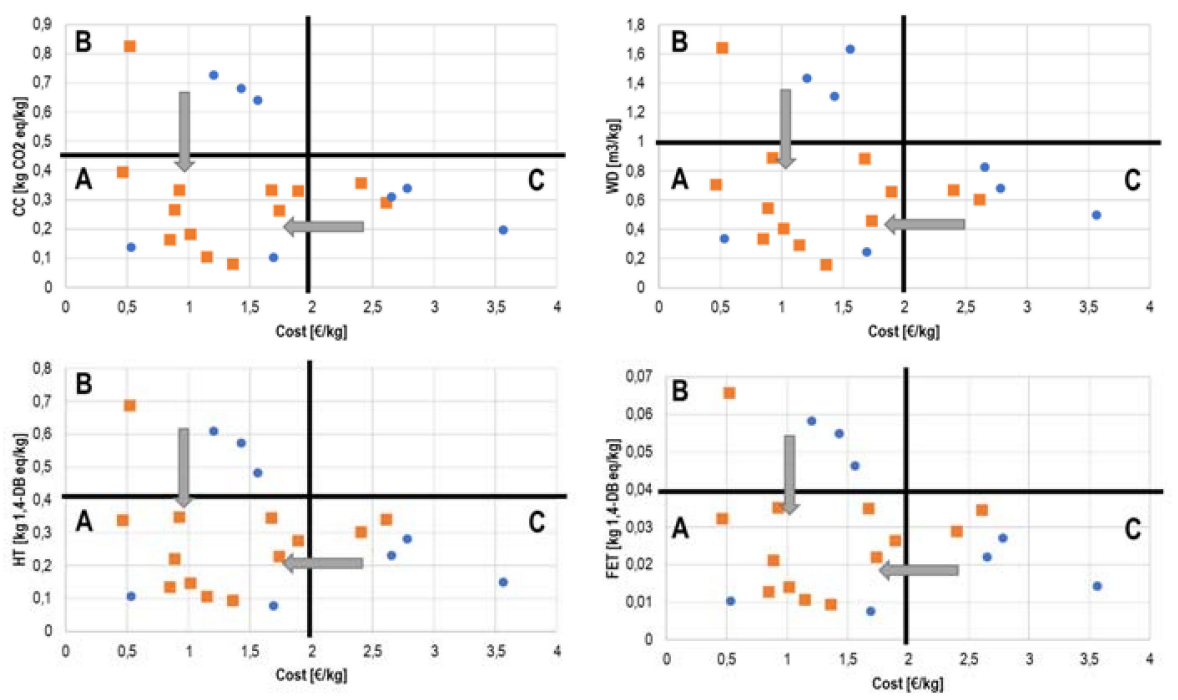

Figure 5. Eco-efficiency of home gardening for climate change (CC), water depletion (WD), human toxicity (HT) and freshwater ecotoxicity (FET). The chart includes leafy vegetables (orange squares) and fruit vegetables (blue dots). Grey arrows indicate desired trend.

\subsection{Food Security Potential}

According to production values, the total harvest of $161.8 \mathrm{~kg}$ of vegetables could represent supply for between 1.11 and 2.10 people in the gardener's household (Figure 6). Such figures represent that, with the evaluated crop design and outputs, a person could satisfy their vegetable requirements with a garden size of between $11.9 \mathrm{~m}^{2}$ and $22.6 \mathrm{~m}^{2}$ (Figure 6). However, one may notice that the most restricting food security perspective-the health perspective of $400 \mathrm{~g}$ of fruit and vegetables a day-considers full accomplishment only with vegetables. From a consumption perspective, the production of the home garden can fulfill the annual requirements of 5.6 persons for leafy vegetables, 1.6 persons for tomatoes and 4.3 persons for other fruit vegetables.

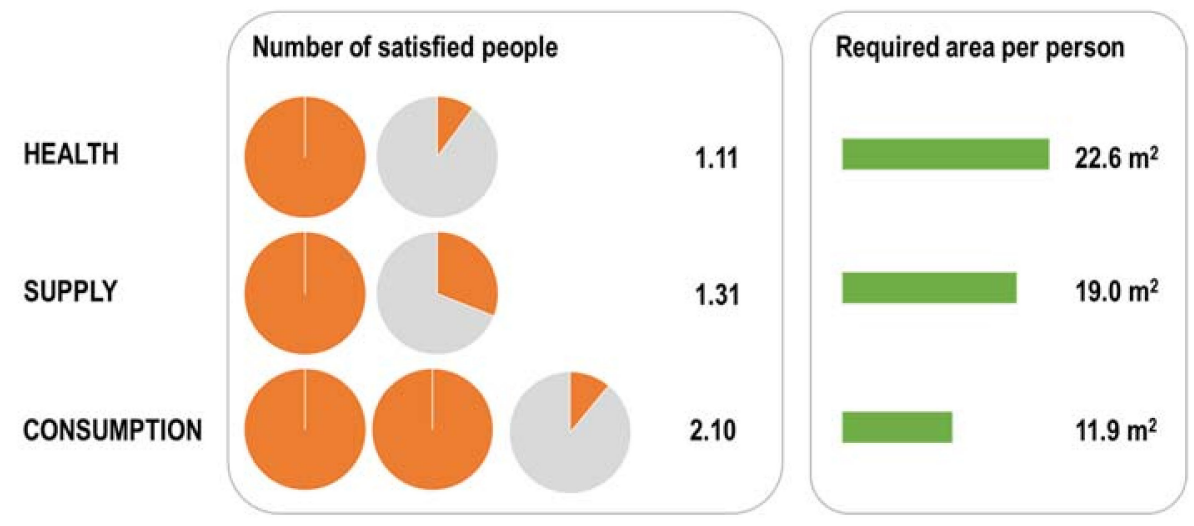

Figure 6. Food self-sufficiency potential of the home garden in terms of number of satisfied people and the corresponding required area per person, from a health, supply and consumption perspective.

\section{Discussion}

This study evaluated the environmental, economic and food security impact of home gardens as a traditional form of UA. In the context of available literature, the environmental impact of this home garden was within the range of open-air UA production. For climate change (Figure 7), tomato and lettuce environmental data were available for different UA forms and case studies. Home-grown tomatoes had a slightly higher environmental impact than soil-based urban farms in the United 
States [47] and a rooftop garden in Italy [48]. The impact was significantly lower when compared to an open-air rooftop farm in the USA [47] and community farming with organic practices in the United Kingdom [50]. In the case of lettuce, differences with other case studies were less significant, apart from a urban farm case in the USA with a high crop yield performance [47].

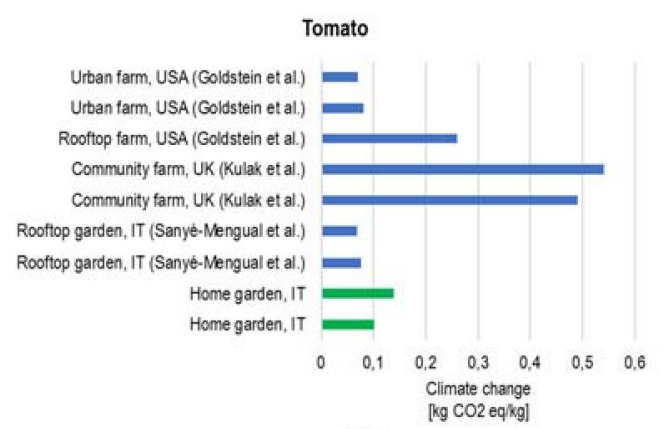

(a)

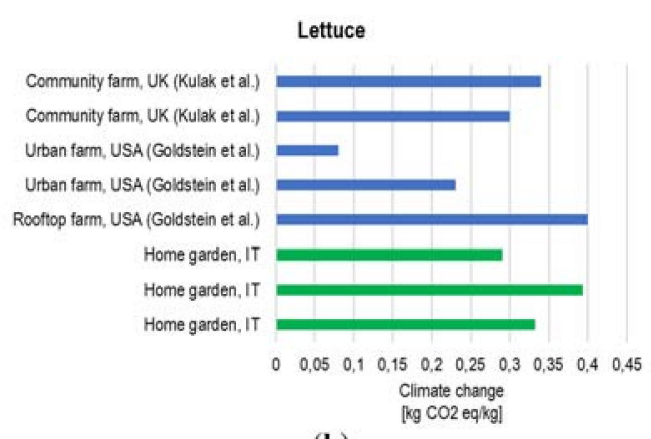

(b)

Figure 7. Comparison of the climate change impact of tomato (a) and lettuce (b) production in the home garden under assessment with open-air UA production literature data.

While for home gardens, tap water, fertilization and pest management were the most relevant life cycle stages in the different environmental impact categories, differences were found with other case studies in the literature. The community rooftop garden in Bologna (Italy) employed electrical devices for automatic fertigation of the garden leading to a large consumption of electricity. Due to the current electricity mix in Italy, this resource consumption had a relevant impact on the environmental indicators [48]. Furthermore, the cost of the auxiliary equipment required for this automatization was also the main contributor to the life cycle costing [48]. In this home garden, the employment of manual techniques was enhanced, and thus offered a higher eco-efficiency. Both, Goldstein et al. [47] and Kulak et al. [50] identified the embodied greenhouse gas emissions (GHG) of the capital resources (i.e., materials of the structure and the auxiliary equipment) as the largest contribution to global warming. However, our study did not find differences between the same product when employing auxiliary equipment (e.g., tunnel), as the specific variety and the crop yield were more determinant in the environmental impact value.

\subsection{Eco-Efficiency and Crop Management}

The environmental assessment indicated that organic fertilization, use of tap water, mineral fertilization and pesticides were the most contributing elements of the life cycle. The case study under assessment followed low-input agronomic practices, minimizing the consumption of certain resources. In particular, this home garden showed a great advantage of employing a manual management, while avoiding the use of electronic devices to automatize irrigation, which was a relevant element of the environmental burdens of community gardening in a case study in Bologna (Italy) [48]. Along the same lines, these manual practices also benefited the economic cost of the home-grown products, which resulted in economic savings for the gardener.

According to the results of this study, crop management could be improved to minimize environmental burdens and economic costs. First, the dosages of fertilizers, water and pesticides could be adapted to crop requirements, avoiding the current homogeneous application. The need of differentiating dosages according to diverse crops was already highlighted in the literature of urban agriculture [36,48]. For this case study, the applied rates of nitrogen fertilization were around $220 \mathrm{~kg} \mathrm{~N} \cdot \mathrm{ha}^{-1}$ in most of the crop cycles. Although this rate remained within the range of previous indications for vegetable crops (e.g., 89 to $190 \mathrm{~kg} \mathrm{~N} \cdot \mathrm{ha}^{-1}$ for tomatoes [74], 145 to $344 \mathrm{~kg} \mathrm{~N} \cdot \mathrm{ha}^{-1}$ for lettuces [75,76], 180 to $600 \mathrm{~kg} \mathrm{~N} \cdot \mathrm{ha}^{-1}$ for cabbage [77]), the amount could result in significant leaching losses. Furthermore, the winter irrigation rate was larger than the expected rate in professional 
agriculture. These aspects highlighted the relevance of agricultural knowledge in crop management, the resulting resources consumption and the consequent environmental impacts and economic costs.

Second, the use of organic compost was linked to large contributions to environmental impacts due to the origin of organic waste, i.e., municipal solid waste. The employment of specific typologies of compost with green waste could reduce such impacts. Furthermore, self-composting could be performed in the garden by employing household and garden bio-waste, promoting a closed system that would provide these urban wastes with a second life, as usually enhanced in UA practices [78]. Third, tap water could be substituted by alternative water sources that are not linked to the water provision system, such as rainwater harvesting. Finally, the use of pesticides showed large burdens in eco-toxicity categories and, thus, a reduced use of these chemicals by employing integrated pest management would positively affect these impact categories, as promoted by the Directive of Sustainable use of pesticides [79]. Furthermore, such an approach would indirectly benefit the biodiversity of the garden and the ecosystem services related to habitat provision and pollination.

\subsection{Implications of Crop Design}

The evaluation of multiple vegetable crops unveiled the relevance of garden design and crop selection in the eco-efficiency of home gardens. The varieties of certain species can largely affect the environmental and economic outputs as the performance, i.e., crop yield, can vary. In this case study, different varieties of chicory, lettuces and tomato were cultivated. In the case of chicory, the "Catalogna" variety yielded almost 10 times more than "Treviso". This fact resulted in "Catalogna" being the least impacting crop in environmental terms and "Treviso" the most impacting one. On the contrary, the two varieties of lettuce- "Gentile" and "Cappuccia"—-showed no significant difference in terms of crop yield or environmental impact. Finally, tomato varieties (bunch and table) showed crop yield and environmental impact differences but were still the least-impacting fruit vegetable crops.

Less eco-efficient varieties may be substituted by new crops in the garden to diversify the harvest, as polyculture home gardens are beneficial towards ensuring food security and improving healthy diet habits [80]. On the other hand, leguminous crops were the most impacting ones in environmental terms among the fruit crops. However, such crops provide a source of vegetable protein to the gardener and more environmentally-friendly practices may be applied instead of substituting such species from the garden design.

According to the food security analysis, the assessed home garden could satisfy the food requirements of between 1 and 2 members of the household, depending on the considered perspective. Considering the most restricting perspective (health perspective: $400 \mathrm{~g}$ of fruit and vegetables a day), food security could be improved through crop design by including fruit crops (e.g., melon, watermelon, strawberries) as new crops, which could substitute the least eco-efficient varieties identified in this study. Such changes will increase not only eco-efficiency but also food security. Fruit crops were included in the design of the community rooftop garden in Bologna, Italy, satisfying the vegetables and fruit requirements of some social housing inhabitants who participated in garden management [81].

\section{Conclusions}

This paper contributed to literature with the first comprehensive evaluation of the economic and environmental burdens of home gardens as a form of UA. Furthermore, the food security potential of the garden was evaluated to deepen the role of home gardens in urban food systems. The environmental burdens of a home garden were mostly related to crop practices, as a low-input type of UA characterized by low automatization and manual labor. Furthermore, economic costs can be affected by the niche market of urban gardening, such as the high costs of seedlings.

The practices recommended to improve the eco-efficiency of home gardens should focus on minimization of the use of chemicals, promotion of renewable and endogenous resources (e.g., rainwater, home-made compost), diffusion of nursing, and integrated pest management. The design of the garden and the crop selection can determine the overall impact of the garden, 
as certain varieties yield better, and can make a more diversified contribution to household food security.

Further research may focus on the eco-efficiency assessment of best practices to minimize the environmental and economic burdens of home gardens. The quantification and inclusion of other social benefits of home gardening, beyond food security, may shed light on the comprehensive contribution to sustainability of home gardening. The analysis of other case studies in the same study area (Padua, Veneto) as well as in Italy could provide further evidence, beyond this case study, as a basis for cross-case learning, results generalization, and identification of best practices towards sustainable home gardens. To improve LCI coverage, direct measurements of lixiviates might be included in further assessments. Finally, as climatic conditions are determinants for agricultural production, the replication of this assessment in home gardens of different climatic areas may provide further knowledge on the geographic variability and effects on sustainability impacts of home gardening.

Author Contributions: E.S.-M. analyzed the data and wrote the paper; D.G. collected data and contributed to first drafts of the paper; N.M. contributed to the data collection process; G.P. designed and performed the agronomic experiments; F.O. and G.G. revised the paper.

Funding: This project received funding from the European Union's Horizon 2020 research and innovation programme under the Marie Sklodowska-Curie grant agreement No. 708672.

Conflicts of Interest: The authors declare no conflict of interest.

\section{Appendix A. Cost Data}

Table A1 displays the unitary cost per element of the life cycle of home-grown food.

Table A1. Unitary cost and source, by element of the life cycle of home-grown food (* For seeds and seedlings, a range of the price is here provided, as it depends on the variety, see Tables A2 and A3).

\begin{tabular}{cccc}
\hline Element & Cost & Unit & Source \\
\hline Land occupation & - & & \\
Nonwoven fabric & 11.75 & $€ / \mathrm{kg}$ & Specialized seller \\
Tunnel rods & 5.55 & $€ / \mathrm{kg}$ & Specialized seller \\
Plant net & 12.55 & $€ / \mathrm{kg}$ & Specialized seller \\
Tubes & 2.175 & $€ / \mathrm{kg}$ & Specialized seller \\
Tap water & 0.00139 & $€ / \mathrm{L}$ & Local water provider \\
Seeds * & $6.4-30$ & $€ / \mathrm{kg}$ & Specialized seller \\
Seedlings & $0.14-3.53$ & $€ / \mathrm{p}$ & Average of market prices \\
Industrial compost & 1.6 & $€ / \mathrm{kg}$ & Specialized seller \\
NPK 6-12-24 & 5.50 & $€ / \mathrm{kg}$ & Specialized seller \\
Ammonium nitrate NH $\mathrm{NO}_{3}$ & 0.575 & $€ / \mathrm{kg}$ & Specialized seller \\
Copper sulfate & 5.00 & $€ / \mathrm{kg}$ & Specialized seller \\
Distribution transport & 0.206 & $€ / \mathrm{kgkm}$ & Estimation \\
Gardener transport & 0.602 & $€ / \mathrm{kgkm}$ & Estimation \\
\hline
\end{tabular}

Table A2 displays the unitary cost per seedling, by crop. The values resulted from the average of the market price in three different nursery firms of the study area. 
Table A2. Seedling cost, by crop.

\begin{tabular}{ccc}
\hline Element & Cost & Unit \\
\hline Fennel & 0.31 & $€ /$ seedling \\
Chard & 0.36 & $€ /$ seedling \\
Lett. Cappuccia & 0.25 & $€ /$ seedling \\
Cabbagge cappuccio & 0.30 & $€ /$ seedling \\
Lett. Gentile & 0.25 & $€ /$ seedling \\
Zucchini & 1.03 & $€ /$ seedling \\
Celery & 0.56 & $€ /$ seedling \\
Tomato grappolo & 0.94 & $€ /$ seedling \\
Tomato tondo & 0.94 & $€ /$ seedling \\
Pepper & 0.94 & $€ /$ seedling \\
Eggplant & 3.53 & $€ /$ seedling \\
Chicory “Catalogna” & 0.14 & $€ /$ seedling \\
Chicory “Treviso" & 0.26 & $€ /$ seedling \\
Cabbage Verza & 0.49 & $€ /$ seedling \\
\hline
\end{tabular}

Table A3 shows the specific cost for seeds, by crop. Seeds' cost was obtained from the specialized seller that provided the seeds in this assessment.

Table A3. Seeds cost, by crop.

\begin{tabular}{ccc}
\hline Element & Cost & Unit \\
\hline Peas & 6.8 & $€ / \mathrm{kg}$ \\
Spinach & 24 & $€ / \mathrm{kg}$ \\
Chicory "grumolo" & 22 & $€ / \mathrm{kg}$ \\
String beans & 30 & $€ / \mathrm{kg}$ \\
\hline
\end{tabular}

\section{Appendix B. Indicators' Contribution to the Normalized Impact}

The following tree diagram displays the relevance of the different ReCiPe indicators in the normalized value:

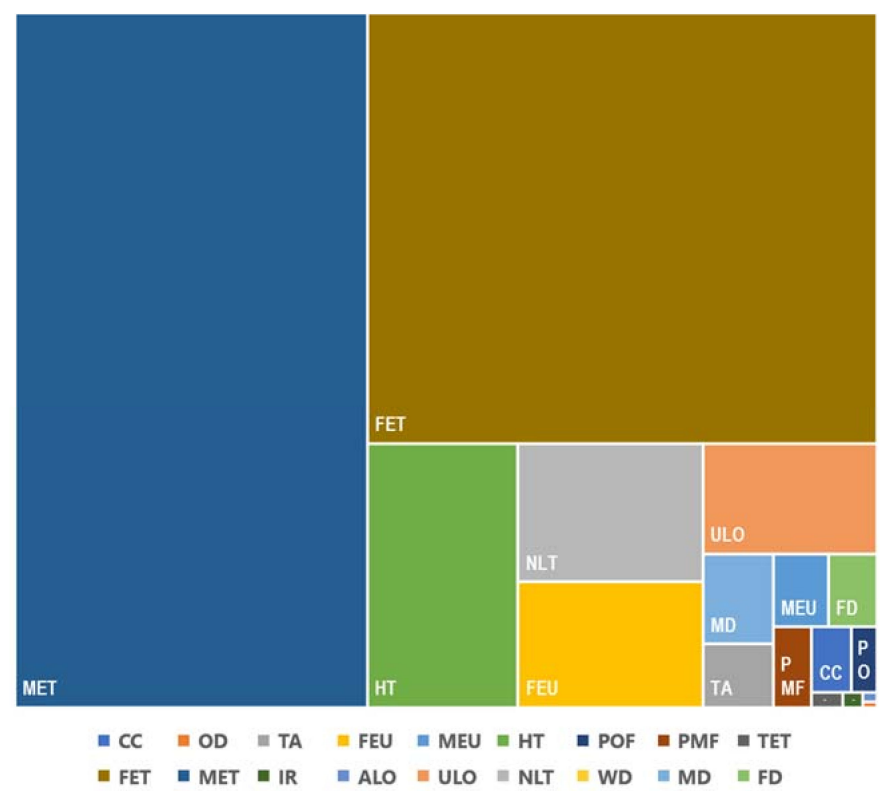

Figure A1. Contribution of the individual ReCiPe midpoint indicators to the normalized value. 


\section{Appendix C. Cost Comparison with Market Prices}

The total cost of home-grown products was compared with market prices, including the Italian market (national statistics), the bio market and the local market. The cost balance was calculated as:

$$
\text { Cost balance }\left(\frac{€}{\mathrm{~kg}}\right)=\text { Market price }\left(\frac{€}{\mathrm{~kg}}\right)-\text { Total cost }\left(\frac{€}{\mathrm{~kg}}\right)
$$

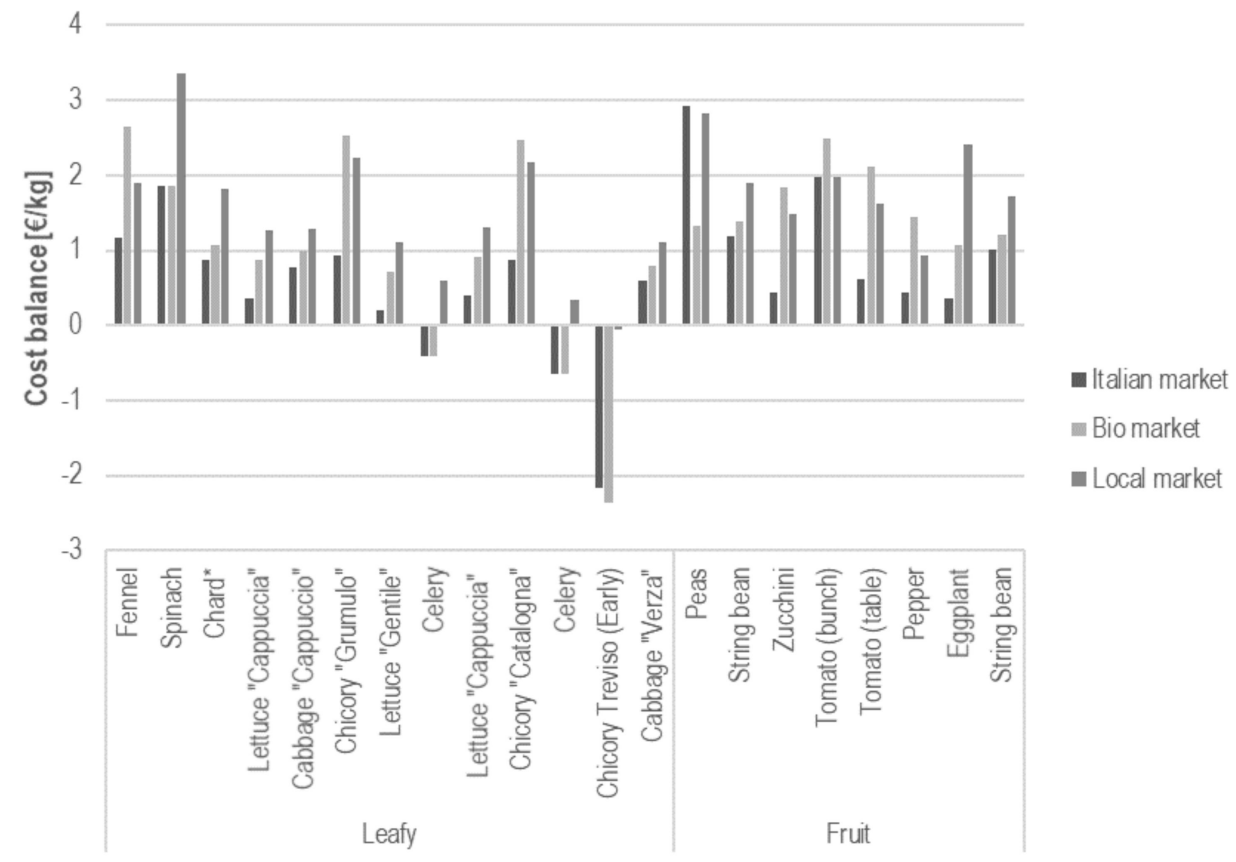

Figure A2. Cost balance comparing to the Italian market, bio market and local market, by crop and vegetable type.

\section{References}

1. Department of Economic and Social Affairs. Population Division. In World Population Prospects: The 2017 Revision; Department of Economic and Social Affairs: New York, NY, USA, 2017.

2. Van Kamp, I.; Leidelmeijer, K.; Marsman, G.; de Hollander, A. Urban environmental quality and human well-being. Landsc. Urban Plan. 2003, 65, 5-18. [CrossRef]

3. Pimentel, D.; Huang, X.; Cordova, A.; Pimentel, M. Impact of Population Growth on Food Supplies and Environment. Popul. Environ. 1997, 19, 9-14. [CrossRef]

4. Newman, P. The environmental impact of cities. Environ. Urban. 2006, 18, 275-295. [CrossRef]

5. Girardet, H. Regenerative Cities; Commission on Cities and Climate Change-World Future Council: Hamburg, Germany, 2010.

6. Biel, R. Sustainable Food Systems; London, U.C., Ed.; UCL Press: London, UK, 2016.

7. Couch, C.; Fraser, C.; Percy, S. Urban Regeneration in Europe; John Wiley \& Sons: Hoboken, NJ, USA, 2008.

8. McLain, R.; Poe, M.; Hurley, P.T.; Lecompte-Mastenbrook, J.; Emery, M.R. Producing edible landscapes in Seattle's urban forest. Urban For. Urban Green. 2012, 11, 187-194. [CrossRef]

9. McClintock, N. From Industrial Garden to Food Desert: Demarcated Devalution in the Flatlands of Oakland, California. In Cultivating Food Justice: Race, Class, and Sustainability; Alkon, A., Agyeman, J., Eds.; MIT Press: Cambridge, MA, USA, 2011; pp. 89-120.

10. Anthopoulou, T.; Partalidou, M.; Moyssidis, M. Emerging municipal garden-allotments in Greece in times of economic crisis: Greening the city or combating urban neo-poverty. In Proceedings of the XXV ESRS Congress: Laboratorio Di Studi Rurali SISMONDI, Florence, Italy, 29 July-1 August 2013. 
11. Camps-Calvet, M.; Langemeyer, J.; Calvet-Mir, L.; Gómez-Baggethun, E.; March, H. Sowing Resilience and Contestation in Times of Crises: The Case of Urban Gardening Movements in Barcelona. PArtecipazione e COnflitto 2015, 8, 417-442.

12. Mok, H.-F.F.; Williamson, V.G.; Grove, J.R.; Burry, K.; Barker, S.F.; Hamilton, A.J. Strawberry fields forever? Urban agriculture in developed countries: A review. Agron. Sustain. Dev. 2014, 24, 21-43. [CrossRef]

13. Teig, E.; Amulya, J.; Bardwell, L.; Buchenau, M.; Marshall, J.A.; Litt, J.S. Collective efficacy in Denver, Colorado: Strengthening neighborhoods and health through community gardens. Health Place 2009, 15, 1115-1122. [CrossRef] [PubMed]

14. Baker, L.E. Tending Cultural Landscapes and Food Citizenship in Toronto's Community Gardens. Geogr. Rev. 2013, 94, 305-325. [CrossRef]

15. Saldivar-Tanaka, L.; Krasny, M.E. Culturing community development, neighborhood open space, and civic agriculture: The case of Latino community gardens in New York City. Agric. Hum. Values 2004, 21, $399-412$. [CrossRef]

16. Anguelovski, I. Beyond a Livable and Green Neighborhood: Asserting Control, Sovereignty and Transgression in the Casc Antic of Barcelona. Int. J. Urban Reg. Res. 2013, 37, 1012-1034. [CrossRef]

17. Sanyé-Mengual, E.; Anguelovski, I.; Oliver-Solà, J.; Montero, J.I.; Rieradevall, J. Resolving differing stakeholder perceptions of urban rooftop farming in Mediterranean cities: Promoting food production as a driver for innovative forms of urban agriculture. Agric. Hum. Values 2016, 33, 101-120. [CrossRef]

18. Gasperi, D.; Pennisi, G.; Rizzati, N.; Magrefi, F.; Bazzocchi, G.; Mezzacapo, U.; Stefani, M.C.; Sanyé-Mengual, E.; Orsini, F.; Gianquinto, G. Towards regenerated and productive vacant areas through urban horticulture: Lessons from Bologna, Italy. Sustainability 2016, 8, 1347. [CrossRef]

19. Schwarz, K.; Cutts, B.B.; London, J.K.; Cadenasso, M.L. Growing gardens in shrinking cities: A solution to the soil lead problem? Sustainability 2016, 8, 141. [CrossRef]

20. Oda, K.; Rupprecht, C.D.D.; Tsuchiya, K.; McGreevy, S.R. Urban Agriculture as a Sustainability Transition Strategy for Shrinking Cities? Land Use Change Trajectory as an Obstacle in Kyoto City, Japan. Sustainability 2018, 10, 1048. [CrossRef]

21. Sioen, G.B.; Sekiyama, M.; Terada, T.; Yokohari, M. Post-Disaster Food and Nutrition from Urban Agriculture: A Self-Sufficiency Analysis of Nerima Ward, Tokyo. Int. J. Environ. Res. Public Health 2017, 14, 748. [CrossRef] [PubMed]

22. Gottlieb, R.; Joshi, A. Food Justice; The MIT Press: Cambridge, MA, USA, 2010.

23. Reynolds, K.; Cohen, N. Beyond the Kale. Urban Agriculture and Social Justice Activism in New York City; University of Georgia Press: Athens, Greece, 2016.

24. Weatherell, C.; Tregear, A.; Allinson, J. In search of the concerned consumer: UK public perceptions of food, farming and buying local. J. Rural Stud. 2003, 19, 233-244. [CrossRef]

25. Pittari, J.J., Jr. From Garden City to Green City: The Legacy of Ebenezer Howard. Am. Plan. Assoc. 2003, $69,450$.

26. Odom, W. Mate, we don't need a chip to tell us the soil's dry: Opportunities for designing interactive systems to support urban food production. In Proceedings of the 8th ACM Conference on Designing Interactive Systems, Aarhus, Denmark, 16-20 August 2010; pp. 232-235.

27. Lim, C.J. Food City; Routledge: Abingdon-on-Thames, UK, 2014.

28. Pascale, L.; Orsini, F.; Gianquinto, G. AGRIlive: Modular hydroponic online supported gardens for zero km agriculture. In Proceedings of the XI International People Plant Symposium on Diversity: Towards a New Vision of Nature, Baarlo, The Netherlands, 6-8 September 2012; Volume 1093, pp. 73-81.

29. Despommier, D. The rise of vertical farms. Sci. Am. 2009, 301, 80-87. [CrossRef] [PubMed]

30. Thomaier, S.; Specht, K.; Henckel, D.; Dierich, A.; Siebert, R.; Freisinger, U.B.; Sawicka, M. Farming in and on urban buildings: Present practice and specific novelties of Zero-Acreage Farming (ZFarming). Renew. Agric. Food Syst. 2015, 30, 43-54. [CrossRef]

31. Ferris, J.; Norman, C.; Sempik, J. People, Land and Sustainability: Community Gardens and the Social Dimension of Sustainable Development. Soc. Policy Adm. 2001, 35, 559-568. [CrossRef]

32. Pölling, B.; Mergenthaler, M.; Lorleberg, W. Professional urban agriculture and its characteristic business models in Metropolis Ruhr, Germany. Land Use Policy 2016, 58, 366-379. [CrossRef]

33. Zezza, A.; Tasciotti, L. Urban agriculture, poverty, and food security: Empirical evidence from a sample of developing countries. Food Policy 2010, 35, 265-273. [CrossRef] 
34. Mougeot, L.J.A. Urban agriculture: Definition, presence, potential and risks. In Growing Cities, Growing Food: Urban Agriculture on the Policy Agenda; Bakker, N., Ed.; DSE: Feldafing, Germany, 2000; pp. 1-62.

35. Food and Agriculture Organization (FAO). Urban and Periúrban Agriculture: A Briefing Guide for the Successful Implementation of URBAN and Peri-Urban Agriculture in Developing Countries and Countries of Transition; FAO: Rome, Italy, 2001.

36. Sanyé-Mengual, E. Sustainability Assessment of Urban Rooftop Farming Using an Interdisciplinary Approach; Universitat Autonòma de Barcelona: Bellaterra, Spain, 2015.

37. Urban Agriculture Europe. COST ACTION Urban Agriculture Europe. Available online: http://www. urban-agriculture-europe.org/ (accessed on 10 February 2018).

38. Lohrberg, F.; Timpe, A. COST Action Urban Agriculture Europe: Documentation 1st Working Group Meeting Editors; RWTH Aachen University: Aachen, Germany, 2012.

39. Kortright, R.; Wakefield, S. Edible backyards: A qualitative study of household food growing and its contributions to food security. Agric. Hum. Values 2010, 28, 39-53. [CrossRef]

40. Hamm, M.W.; Bellows, A.C. Community food security and nutrition educators. J. Nutr. Educ. Behav. 2003, 35, 37-43. [CrossRef]

41. Bohn, K.; Viljoen, A. The Edible City: Envisioning the Continuous Productive Urban Landscape (CPUL). Field J. 2011, 4, 149-161.

42. Taylor, J.R.; Taylor Lovell, S. Mapping public and private spaces of urban agriculture in Chicago through the analysis of high-resolution aerial images in Google Earth. Landsc. Urban Plan. 2012, 108, 57-70. [CrossRef]

43. Pulighe, G.; Lupia, F. Mapping spatial patterns of urban agriculture in Rome (Italy) using Google Earth and web-mapping services. Land Use Policy 2016, 59, 49-58. [CrossRef]

44. Taylor, J.R.; Lovell, S.T. Urban home gardens in the Global North: A mixed methods study of ethnic and migrant home gardens in Chicago, IL. Renew. Agric. Food Syst. 2014, 30, 22-32. [CrossRef]

45. Taylor, J.R.; Lovell, S.T. Urban home food gardens in the Global North: Research traditions and future directions. Agric. Hum. Values 2013, 31, 285-305. [CrossRef]

46. Syme, G.J.; Shao, Q.; Po, M.; Campbell, E. Predicting and understanding home garden water use. Landsc. Urban Plan. 2004, 68, 121-128. [CrossRef]

47. Goldstein, B.; Hauschild, M.; Fernández, J.; Birkved, M. Testing the environmental performance of urban agriculture as a food supply in northern climates. J. Clean. Prod. 2016, 135, 984-994. [CrossRef]

48. Sanyé-Mengual, E.; Orsini, F.; Oliver-Solà, J.; Rieradevall, J.; Montero, J.; Gianquinto, G. Techniques and crops for efficient rooftop gardens in Bologna, Italy. Agron. Sustain. Dev. 2015, 35, 1477-1488. [CrossRef]

49. Sanyé-Mengual, E.; Oliver-Solà, J.; Montero, J.I.; Rieradevall, J. An environmental and economic life cycle assessment of Rooftop Greenhouse (RTG) implementation in Barcelona, Spain. Assessing new forms of urban agriculture from the greenhouse structure to the final product level. Int. J. Life Cycle Assess. 2015, 20, 350-366. [CrossRef]

50. Kulak, M.; Graves, A.; Chatterton, J. Reducing greenhouse gas emissions with urban agriculture: A Life Cycle Assessment perspective. Landsc. Urban Plan. 2013, 111, 68-78. [CrossRef]

51. He, X.; Qiao, Y.; Liu, Y.; Yin, C.; Martin, F. Environmental impact assessment of organic and conventional tomato production in urban greenhouses of Beijing city, China. J. Clean. Prod. 2016, 134, 251-258. [CrossRef]

52. Rothwell, A.; Ridoutt, B.; Page, G.; Bellotti, W. Environmental performance of local food: Trade-offs and implications for climate resilience in a developed city. J. Clean. Prod. 2016, 14, 420-430. [CrossRef]

53. Pérez-Neira, D.; Grollmus-Venegas, A. Life-cycle energy assessment and carbon footprint of peri-urban horticulture. A comparative case study of local food systems in Spain. Landsc. Urban Plan. 2018, 172, 60-68. [CrossRef]

54. Maucieri, C.; Forchino, A.A.; Nicoletto, C.; Junge, R.; Pastres, R.; Sambo, P.; Borin, M. Life cycle assessment of a micro aquaponic system for educational purposes built using recovered material. J. Clean. Prod. 2018, 172, 3119-3127. [CrossRef]

55. Forchino, A.A.; Lourguioui, H.; Brigolin, D.; Pastres, R. Aquaponics and sustainability: The comparison of two different aquaponic techniques using the Life Cycle Assessment (LCA). Aquac. Eng. 2017, 77, 80-88. [CrossRef]

56. International Organization for Standardization (ISO). ISO 14040: Life Cycle Assessment—Principles and Framework. Environ. Manag. 2006, 3, 28. 
57. International Organization for Standardization (ISO). ISO 14044: Environmental Management-Life Cycle Assessment-Requirements and Guidelines; ISO: Geneva, Switzerland, 2006.

58. UNEP/SETAC Life Cycle Initiative. Towards a Life Cycle Sustainability a Ssessment: Making Informed Choices on Products; UNEP-SETAC Life-Cycle Initiative: Paris, France, 2011.

59. European Commission-Joint Research Centre-Institute for Environment and Sustainability (EC-JRC). International Reference Life Cycle Data System (ILCD) Handbook: General Guide for Life Cycle Assessment-Detailed Guidance; Publications Office of the European Union: Luxembourg, 2010.

60. Stoessel, F.; Juraske, R.; Pfister, S.; Hellweg, S. Life cycle inventory and carbon and water foodprint of fruits and vegetables: Application to a swiss retailer. Environ. Sci. Technol. 2012, 46, 3253-3262. [CrossRef] [PubMed]

61. Martínez-Blanco, J.; Colón, J.; Gabarrell, X.; Font, X.; Sánchez, A.; Artola, A.; Rieradevall, J. The use of life cycle assessment for the comparison of biowaste composting at home and full scale. Waste Manag. 2010, 30, 983-994. [CrossRef] [PubMed]

62. Audsley, E. Harmonisation of Environmental Life Cycle Assessment for Agriculture; Final Report Concerted Action AIR 3-CT94-2028; European Commission DG VI Agriculture: Silsoe, UK, 1997.

63. Bentrup, F.; Küesters, J. Methods to estimate the potential $\mathrm{N}$ emissions related to crop production. In Agricultural Data for Life Cycle Assessment; Wedeima, B., Meeusen, M., Eds.; Agricultural economics research institute: The Hague, The Netherlands, 2000; Volume 1, pp. 133-151.

64. ISPRA. Urban Waste Report-2017 Edition; ISPRA: Roma, Italy, 2017.

65. PRé Consultants. SimaPro Software Version 8.3; PRé Consultants: Amersfoort, The Netherlands, 2017.

66. ISO. ISO 14040: Environmental Management_Life Cycle Assessment_Principles and Framework; ISO: Geneva, Switzerland, 2006.

67. Goedkoop, M.; Heijungs, R.; Huijbregts, M.; De Schryver, A.; Struijs, J.; Van Zelm, R. ReCiPe 2008, a Life Cycle Impact Assessment Method Which Comprises Harmonised Category Indicators at the Midpoint and the Endpoint Level; First edition Report I: Characterisation; Ministerie van VROM: Den Haag, The Netherlands, 2009.

68. ISMEA. National Market Observatory. Available online: http:/ / osservaprezzi.sviluppoeconomico.gov.it (accessed on 30 March 2018).

69. Campi Aperti Price of Biological Products. Available online: https://www.campiaperti.org/prodotti/ ortaggi/ (accessed on 30 March 2018).

70. Wernet, G.; Bauer, C.; Steubing, B.; Reinhard, J.; Moreno-Ruiz, E.; Weidema, B. The ecoinvent database version 3 (part I): overview and methodology. Int. J. Life Cycle Ass. 2016, 21, 1218-1230. [CrossRef]

71. World Health Organization (WHO). Healthy Diet At Least $400 \mathrm{~g}$ (5 Portions) of Fruits and Vegetables a Day (2). Potatoes, Sweet Potatoes, Cassava and Other Starchy Roots Are Not Classified as Fruits or Vegetables. Available online: http://www.who.int/news-room/fact-sheets/detail/healthy-diet (accessed on 28 March 2018).

72. FAO. FAOSTAT. Available online: http://www.fao.org/faostat/en/\#data/FBS (accessed on 28 March 2018).

73. Sette, S.; Le Donne, C.; Piccinelli, R.; Arcella, D.; Turrini, A.; Leclercq, C. The third Italian National Food Consumption Survey, INRAN-SCAI 2005-06-Part 1: Nutrient intakes in Italy. Nutr. Metab. Cardiovasc. Dis. 2011, 21, 922-932. [CrossRef] [PubMed]

74. Abdul-Baki, A.A.; Teasdale, J.R.; Korcak, R.F. Nitrogen requirements of fresh-market tomatoes on hairy vetch and black polyethylene mulch. HortScience 1997, 32, 217-221.

75. Bottoms, T.G.; Smith, R.F.; Cahn, M.D.; Hartz, T.K. Nitrogen requirements and N status determination of lettuce. HortScience 2012, 47, 1768-1774.

76. McPharlin, I.R.; Aylmore, P.M.; Jeffery, R.C. Nitrogen requirements of lettuce under sprinkler irrigation and trickle fertigation on a spearwood sand. J. Plant Nutr. 1995, 18, 219-241. [CrossRef]

77. Bing, C.; He, F.Y.; Xu, Q.M.; Yin, B.; Gui-Xin, C.A.I. Denitrification Losses and $\mathrm{N}_{2} \mathrm{O}$ Emissions from Nitrogen Fertilizer Applied to a Vegetable Field. Pedosphere 2006, 16, 390-397.

78. Grard, B.J.-P.; Bel, N.; Marchal, N.; Madre, F.; Castell, J.-F.; Cambier, P.; Houot, S.; Manouchehri, N.; Besancon, S.; Michel, J.-C.; et al. Recycling urban waste as possible use for rooftop vegetable garden. Future Food J. Food Agric. Soc. 2015, 3, 21-34.

79. European Commission. Directive 2009/128/EC of the European Parliament and of the Council of 21 October 2009 Establishing a Framework for Community Action to Achieve the Sus Tainable Use of Pesticides. Off. J. Eur. Union 2009, 309, 71-86. 
80. Algert, S.; Diekmann, L.; Renvall, M.; Gray, L. Community and home gardens increase vegetable intake and food security of residents in San Jose, California. Calif. Agric. 2016, 70, 77-82. [CrossRef]

81. Orsini, F.; Gasperi, D.; Marchetti, L.; Piovene, C.; Draghetti, S.; Ramazzotti, S.; Bazzocchi, G.; Gianquinto, G. Exploring the production capacity of rooftop gardens (RTGs) in urban agriculture: The potential impact on food and nutrition security, biodiversity and other ecosystem services in the city of Bologna. Food Secur. 2014, 6, 781-792. [CrossRef] 